San Jose State University

SJSU ScholarWorks

Master's Theses

Master's Theses and Graduate Research

1994

\title{
An archaeological survey of some major drainages within Henry W. Coe State Park, Santa Clara and Stanislaus Counties, California
}

Theodora Goodrich

San Jose State University

Follow this and additional works at: https://scholarworks.sjsu.edu/etd_theses

\section{Recommended Citation}

Goodrich, Theodora, "An archaeological survey of some major drainages within Henry W. Coe State Park, Santa Clara and Stanislaus Counties, California" (1994). Master's Theses. 755.

DOI: https://doi.org/10.31979/etd.4hwq-qdvb

https://scholarworks.sjsu.edu/etd_theses/755

This Thesis is brought to you for free and open access by the Master's Theses and Graduate Research at SJSU ScholarWorks. It has been accepted for inclusion in Master's Theses by an authorized administrator of SJSU ScholarWorks. For more information, please contact scholarworks@sjsu.edu. 


\section{INFORMATION TO USERS}

This manuscript has been reproduced from the microfilm master. UMI films the text directly from the original or copy submitted. Thus, some thesis and dissertation copies are in typewriter face, while others may be from any type of computer printer.

The quality of this reproduction is dependent upon the quality of the copy submitted. Broken or indistinct print, colored or poor quality illustrations and photographs, print bleedthrough, substandard margins, and improper alignment can adversely affect reproduction.

In the unlikely event that the author did not send UMI a complete manuscript and there are missing pages, these will be noted. Also, if unauthorized copyright material had to be removed, a note will indicate the deletion.

Oversize materials (e.g., maps, drawings, charts) are reproduced by sectioning the original, beginning at the upper left-hand corner and continuing from left to right in equal sections with small overlaps. Each original is also photographed in one exposure and is included in reduced form at the back of the book.

Photographs included in the original manuscript have been reproduced xerographically in this copy. Higher quality $6 " \times$ " 9 " black and white photographic prints are available for any photographs or illustrations appearing in this copy for an additional charge. Contact UMI directly to order.

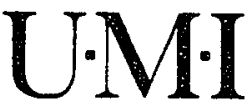

University Microfilms International

A Bell \& Howell Information Company

300 North Zeeb Road. Ann Arbor. MI 48106-1346 USA

$313 / 761-4700 \quad 800 / 521-0600$ 
Order Number 1358179

An archaelogical survey of some major drainages within Henry W. Coe State Park, Santa Clara and Stanislaus counties, California

Goodrich, Theodora Smiley, M.A.

San Jose State University, 1994 


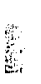

De 


\title{
AN ARCHAEOLOGICAL SURVEY OF SOME MAJOR DRAINAGES WITHIN HENRY W. COE STATE PARK, SANTA CLARA AND STANISLAUS COUNTIES, CALIFORNIA
}

\author{
A Thesis \\ Presented to \\ The Faculty of the Department of Social Science \\ San Jose State University \\ In Partial Fulfillment \\ of the Requirements for the Degree \\ Master of Arts
}

by

Theodora Goodrich

May, 1994 
(c) 1994

Theodora Smiley Goodrich

ALL RIGHTS RESERVED 
APPROVED FOR THE DEPARTMENT OF SOCIAL SCIENCE

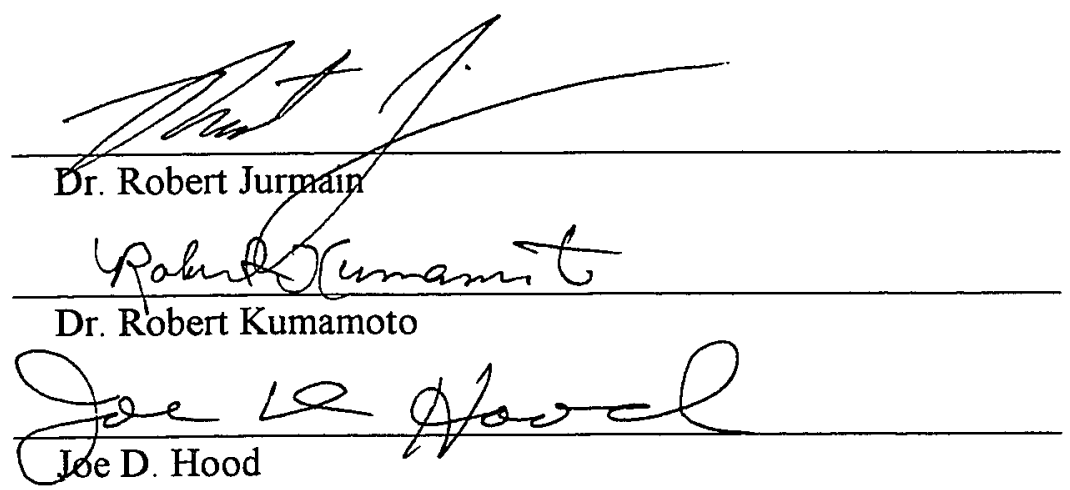

APPROVED FOR THE UNIVERSITY

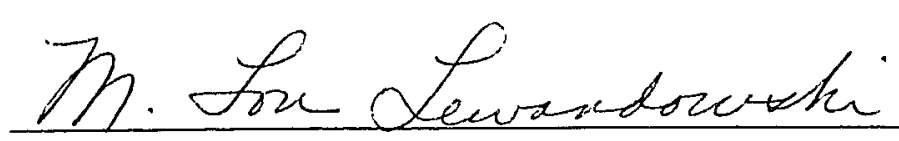




\section{ABSTRACT \\ AN ARCHAEOLOGICAL SURVEY OF SOME MAJOR DRAINAGES WITHIN HENRY W. COE STATE PARK SANTA CLARA AND STANISLAUS COUNTIES, CALIFORNIA}

by Theodora Goodrich

The central portion of the Diablo Range has long been considered to be almost void of an aboriginal population. This assumption has been supported by the journals of early Spanish expeditions and the studies of Twentieth Century ethnographers.

A survey of some of the major drainages within Henry W. Coe State Park reveals numerous sites of various uses. These include sites that reflect aboriginal food gathering and processing, tool making, trade, home construction, and human burials. Further research focusing on this area may reinforce the intensity of aboriginal occupation within the central Diablo Range. 


\section{TABLE OF CONTENTS}

\section{Chapter}

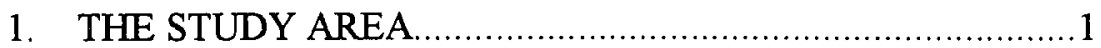

2. THE ABORIGINAL INHABITANTS ..............................5

3. THE ARCHAEOLOGICAL SURVEYS .............................11

Sites within Santa Clara County

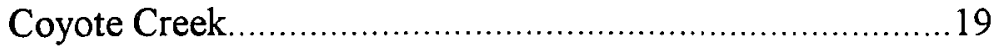

The Upper San Antonio Valley ....................................22

Sites within Stanislaus County

South Fork of Orestimba Creek...................................25

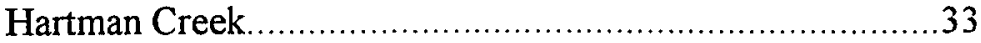

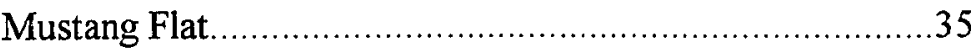

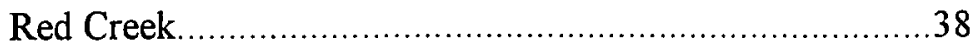

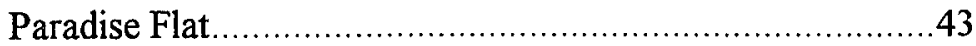

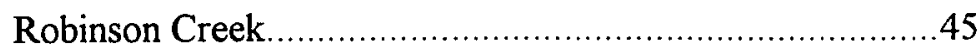

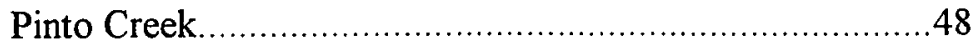

4. SUMMARY AND CONCLUSIONS ...................................50 


\section{LIST OF TABLES}

\section{Table}

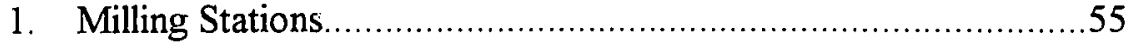

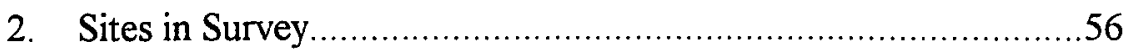

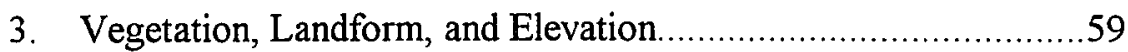

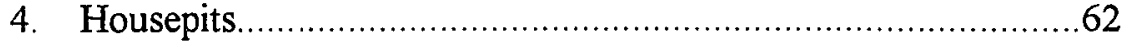

5. Midden Size of Habitation Sites.......................................63 


\section{LIST OF MAPS}

Map

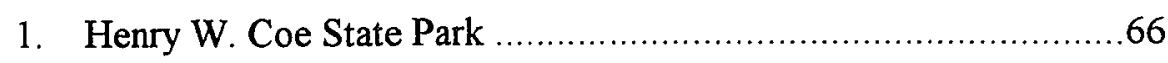

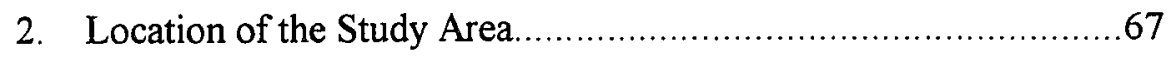

3. Ethnographic Tribal Distribution and Linguistic Groups.............68

4. Sites along Coyote Creek..............................................69

5. Sites along Coyote Creek............................................... 70

6. Sites in the Upper San Antonio Valley and along Red Creek ......71

7. Sites along the South Fork of Orestimba Creek........................72

8. Sites along the South Fork of Orestimba Creek and

Paradise Flat................................................................. 73

9. Sites along the South Fork of Orestimba Creek, Paradise Flat, Red Creek, and Mustang Flat............................................ 74

10. Sites along the South Fork of Orestimba Creek and Robinson

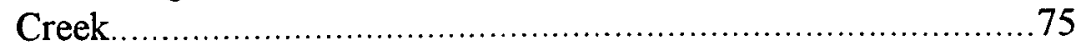

11. Sites along Red Creek and Hartman Creek..........................76

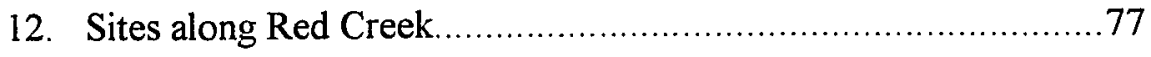

13. Sites along Red Creek............................................... 78

14. Sites along Robinson and Pinto Creeks ..............................79 


\section{CHAPTER ONE}

\section{THE STUDY AREA}

How intensively was the central Diablo Range used by aboriginal populations in prehistoric times? Can the type and intensity of use be determined through a survey of archaeological sites along the major drainages within Henry W. Coe State Park?

The central Diablo Range has long been considered almost void of occupation by aboriginal peoples. Not only was this area considered lacking in human inhabitants, but also in the resources that would sustain life. This assumption is supported by the accounts of Spanish explorers and contemporary ethnographers.

The Anza-Font expedition was the first to explore here. In April 1776 they entered the mountains near the present-day city of Livermore. Journeying in a westerly direction, they traveled through the San Antonio Valley to Coyote Creek and exited the range below Gilroy Hot Springs. Padre Font's journal records an absence of native inhabitants. "In all the journey we did not see a single Indian, although we found some tracks of them, and in places a few signs and traces of ruined huts and villages (Cook 1957, 135-136).

More recent ethnographers reinforced the presumed inhospitable conditions of the mountains and their lack of human population.

"The narrow canyons and brush covered hills of the main axis of the Coast Range were destitute of inhabitants" (Cook 1957, 136). "It is general knowledge that the east side of the valley (San Joaquin) and adjacent foothills were much more heavily populated than the more barren west side" (Cook 1943, 192).

Alfred Kroeber also reinforced the belief that the western foothills of the San Joaquin Valley were almost void of inhabitants. 
Along the west side of the San Joaquin we have a less certain knowledge. This territory seems to have belonged to the Yokuts, though in default of precise information, it has sometimes been attributed to the Costanoan (Ohlone) people or Miwok. This very doubt indicates an unimportant occupation, and while the area was most certainly visited by the Yokuts, and probably claimed by one or more of their northerly neighbors, the number of residents must also have been very few (Kroeber 1925, 476).

Henry W. Coe State Park is located in the Diablo Range south of Mt. Hamilton (Maps land 2). The park encompasses a major portion of the range north of Pacheco Pass, which lies approximately 10 kilometers from the park's southern boundary.

The park was created in 1953 when Sada Coe Robinson donated the family ranch to Santa Clara County for a park to be named in memory of her father. In 1958 the state of California bought the park from the county for the sum of $\$ 10.00$. The Coe Ranch, which was comprised of $4,949.6$ hectares, had been a working cattle ranch since the late 1800 's Included in the property were several parcels that had been purchased by $\mathrm{Mr}$. Coe over the years. These included former homesteads and a mineral springs resort, Madrone Soda Springs. The Thomas property, an inholding of 465.3 hectares, was purchased by the state in 1980.

In 1982 the park grew to 27,350 hectares with the addition of the Frank Coit Ranch, the Dowdy Ranch, and portions of the Gill-Mustang Ranch. These acquisitions spread the park's boundaries across the crest of the Diablo Range into adjacent Stanislaus County.

County Line Road enters the park in the north through the San Antonio Valley and exits about 5 kilometers east of Mustang Peak. This road marks the crest of the Diablo Range within the park and corresponds to the arbitrary dividing line between Northern Valley Yokut and Ohlone territories proposed by Alfred Kroeber early in this century (Kroeber 1925, 486). 
Most of the area west of the crest is comprised of steep ridgelines interspersed with intermediate drainages. On the east side, the terrain is gentler, and the drainages are defined by broad, level valleys.

Summers are generally hot and dry, winters cool and rainy. Temperatures at park headquarters, which lies on the west side of the park, vary from an average high in winter of $15.1^{\circ}$ Celsius to an average low of $5.9^{\circ}$. Summer temperatures range from an average high of $27.2^{\circ}$ to an average low of $16.9^{\circ}$ (Barry Breckling, personal communication, April 1989).

Average rainfall for the period between 1975 and 1989 was $64.52 \mathrm{~cm}$ per year. During this time period a high of $125.90 \mathrm{~cm}$ and a low of $25.93 \mathrm{~cm}$ was recorded (Everett Allen, personal communication, April, 1989).

Historically the land has been used primarily for cattle ranching. Hunting, especially for deer and wild pigs, was popular here, and the American Sportsman Club leased the Gill-Mustang Ranch for hunting for a number of years. During the Depression, fur trappers operated within the park (Peter Enos, personal communication, January 8, 1993). Many homesteads were located here in the early part of this century, but few proved to be financially successful, and with rare exception, a homesteader's tenancy was brief (George Thomas, personal communication, October 3, 1990). Also in the early 1900 's, some persons suffering from tuberculosis took up a brief residency in the hope that the dry air would cure their illness (Phil Stadtler, personal communication, November 6, 1991).

Several mining claims were located within the park. The Blue Ridge Mining District is shown on an 1866 map of Santa Clara County, though the only mine that is identified is the Burra Burra Mine located on the southern slope of the peak of the same name (Official Map of the County of Santa Clara, California, 1866). It is not known what was mined here. Arthur Davenport had mining claims near the eastern boundary of the park where he 
prospected, probably for quicksilver, in the 1930's and 1940's (Gary Davenport, personal communication, October 15, 1992). 


\section{CHAPTER TWO}

\section{THE ABORIGINAL INHABITANTS}

At the time of European contact, the Native Americans who occupied the study area were members of the Penutian Language group (Map 3).

In A.D. 1750 speakers of Penutian tongues occupied nearly half of California . . . . Two aspects of Penutian geography are striking. One is its mass or density, seen as a solid block of about 30 contiguous languages in the California heartland. The other is its spatial relationship to the peripheral Hokan islands. This distribution is probably the result of incursions by Penutians and their spread throughout the Central Valley, fragmenting and leaving in marginal areas the older continuum of Hokan languages (Moratto 1984, 539).

The Penutians extended their occupation by intrusion into an area previously only thinly populated by members of the Hokan language group. According to Kroeber, the people who today call themselves the Ohlone occupied the western portion of the Diablo Range, while those identified as Northern Valley Yokuts occupied the eastern portion of the range (Kroeber 1925, 462). This boundary has been disputed by Milliken, who claims Ohlone occupation for the Diablo Range and beyond to the San Joaquin River (Milliken 1993, 29-59).

The Hokan, who may have occupied the area for as long as 4,000 years before Penutian intrusion, were foragers. Their subsistence pattern included seasonal residential moves among a series of resource patches, gathering of foods daily on an 'encounter' basis with return to a residential base near the end of each day, no use of storage, a limited foraging radius around residential bases, and considerable variability in the redundancy of land use from year to year, and the possible occasional occurrence of extended resource procurement trips from residential bases (Binford 1980, 5). 
Food procurement practices in aboriginal California appear to have gone through several major stages. The first, which may have begun about 12,000 years ago, involved hunting of the large game animals which were the easiest to exploit. As human population increased and territory size decreased, local habitats were exploited more intensely. Many of the large game animals were killed (Wallace 1978a, 28-30).

About 5,000 years ago, there occurred a transition to seed gathering, collection of other plant foods, fishing, and the utilization of small game animals and birds. The final phase in this progression was the shift to acorn collecting and processing. The nutritional value of acorns and their storage capability, fostered the growth of a larger population (Wallace 1978, 28-35).

It appears the Hokan, the area's earliest inhabitants, were either pushed back by the Penutian or were slowly absorbed into the new culture. The spread of the Penutian population becomes evident through the components of the Berkeley Pattern which reflects a change in technology, subsistence pattern, and burial and ceremonial practices. Mortars and pestles become the dominant milling tools and the acorn becomes the primary staple. There is a preference for flexed burials. "Ceremonialism is indicated predominantly by shamanism . . by the presence of . . o objects compatible with known ethnographic 'shaman's kits,' e.g., quartz crystals, charmstones, bone whistles' (Fredrickson 1973, 125-126).

T.F. King has provided a model that explains the Penutian advance and the spread of the Berkeley Pattern. He proposes that settlement would first occur where the widest number of resources were available for exploitation. As the population grew, groups would fission off into adjoining areas, eventually moving into marginal areas where it would be necessary to form exchange systems to provide needed resources (King 1971: 11-14, 1974: 37-42 in Moratto 1984, 282). 
The model ... would explain how dense population fronts associated with fissioning parent settlements might have allowed Utian communities to expand into areas already occupied by groups with different land-use and settlement patterns and lower population densities (Moratto 1984, 282).

The Penutian advance was aided by an altithermal that occurred approximately 1,500-600 B.P. (Breschini et. al. 1983, 20). A hiatus of occupation in the archaeological record indicates a dwindling of population, especially in the San Joaquin Valley. Once the altithermal passed, the Penutian population advanced rapidly through central California. "Findings at Buena Vista Lake, Panoche, and San Luis indicate that populations expanded and settlements proliferated after circa A.D. 1500 in the southern and western portions of the San Joaquin Valley" (Moratto 1984, 215).

The Penutians were already well adapted to the acorn economy. With this food source central to their physical and cultural survival, it seems logical that, as their population grew, they followed this resource into the area that is now Henry W. Coe State Park. "A later emphasis on acorn use coincides with the intensified occupation of foothill oak woodland zones throughout central California (Moratto 1984, 557).

The oak woodland that comprises $57 \%$ of the park (Barry Breckling, personal communication, November 7,1993 ), provided the natives with the primary component of their diet, acorns. This necessary resource may well have influenced the size and location of their habitations.

After the acorns were harvested in the fall of the year, they were transported to the storage area.

The areas of local autonomy, tribelet areas, within which acorns were harvested, were usually very small, however, so transport needed only a large container. One wonders, in fact, whether the economic necessities of acorn transport may not have been largely responsible for determining the minute tribelet areas (Baumhoff 1963, 166). 
Appropriate to the transport of acorns are the estimated catchement areas proposed for hunting and gathering resources in central California. They have alternatively been defined as an area of 25 square kilometers (Stodder 1986, 8), 10 kilometers (Hildebrandt $1984,46)$, or "the area around a settlement that can be exploited efficiently in the course of a day's work; usually an area within 1 or 2 hours' walk from a settlement" (Moratto 1984, 587). Either way, their size has important implications for population movement within the park.

Acorn processing presents

a number of complex problems, especially in processing and consumption. Further, in California, acorns are the only plant food which can be compared with the importance of a modern agricultural crop. Thus, an acorn economy, besides giving rise to a different and more complicated set of exploitation techniques, could be expected to lead to a more complex social organization and a concomitant increase in population. The first of these factors is ordinarily expressed archaeologically by portable and bedrock mortars and the pestle (Elsasser 1986, 36).

Within the park there is ample evidence of acorn processing. Bedrock formations on large boulders in or adjacent to major drainages and springs often contain multiple mortars (Table 1). Portable hopper mortars have been found as well, but probably do not reflect their original numbers. During the years when the parkland was used for cattle production, many were probably gathered for their decorative value.

The social organization that arose from the acorn economy was supported by a complex system of ritual, exogamy, and trade (Bean 1974, 103).

At the local level, organization was controlled through the central community.

There was usually a central town which served as political, ritual, and economic center, and several subordinate, smaller settlements. Council meetings and legal or legislative delegates were held at the principal village, and large caches of food, goods, and treasures were maintained there. The settlements were variously occupied permanently or seasonally; often each had a chief, usually the head of a lineage or extended family ... (Bean 1974, 103). 
Larger alliances based upon trade and ritual

seem to have involved at least three tribelets, often members of different ethnic nationalities, whose ecological potential was mutually useful.

Cross tribelet interfacing appears to have commonly involved peoples within a radius of fifty to seventy-five miles in ritual or trade feast contexts, which sometimes brought several hundred to several thousand people together. Cult centers, such as those described by Kroeber for the World Renewal system are a a case in point. Estudillo observed upwards of three thousand people at a single mourning ceremony. . The economic equilibrium maintained through this network involved as many as a dozen or more villages or tribelets, two or more nationalities, and several ecological zones (e.g., coast, foothill, riverine, mountain) (Bean 1974, 104-105).

Tribal interfacing would have provided much needed trade items not within the ecological basis of the park. Some of the items found on sites within the park provide evidence of trade: obsidian, clam shells, Olivella and Haliotis shells and beads, and points of Monterey banded chert.

It has long been known that Pacheco Pass was used prehistorically as a trade route. Routes inside the park pass from the San Antonio Valley to Orestimba Creek (Beck and Haase 1974, 21), and from Coyote Creek to the south fork of Orestimba Creek (King and Hickman 1973, map \#14 in Elsasser).

Levy identifies the Plains Miwok, the Sierra Miwok, and the Yokuts as the main trading partners of the Ohlone (Levy 1978, 488).

Marriage customs reinforced tribal alliances.

Moiety exogamy was associated with ritual reciprocity, and consequently moieties served to define potential marriage alliances as well as religious, economic, and sometimes military alliances. These . . created very extensive social networks between neighboring groups, since marital partners were necessarily sought from a wide sociological and ecological base (Bean 1974, 105).

According to Kroeber, among the Yokut

Kindred of any known degree of relationship, except perhaps one class of cousins, were ineligible to marriage. The Yokuts state that people of the same tribe and 
town could marry . . . but the vast majority of such specific records reveal marriages between people not of the same tribe. This habit is the more peculiar because the dialects of the tribes always differed somewhat; at the same time, the practice must have been a factor of some influence in preventing the rapid drifting apart of the idiom. Naturally, many of the Yokuts were bilingual; and persons knowing three or four dialects, or even distinct languages, are not rare (Kroeber 1925, 493).

A Yokut man had to marry outside his own inherited social division. This totemic moiety system was passed down from father to son. If a man married outside his tribe "The halves are the same everywhere." He "confines himself to the opposite moiety exactly as if he chose his spouse at home" (Kroeber 1925, 494). Both Yokut and Ohlone had deer and bear moieties; this similarity in structure led to marital alliances between them (Levy 1978, 484). 


\section{CHAPTER THREE}

\section{THE ARCHAEOLOGICAL SURVEYS}

The first archaeological survey of Henry W. Coe State Park was conducted in 1970 by William Olsen and William Pritchard of the California Department of Parks and Recreation. The survey was limited to 4 sites located along the Little and East Forks of Coyote Creek. All 4 of these sites, CA-SCl-73, 74, 75, and 363, are now listed on the National Register of Historic Places.

A second, and more extensive survey, was conducted by E. Breck Parkman, Joe Hood, and John Kelley of the California Department of Parks and Recreation in 1982. During this survey, which took place after the Coit, Dowdy, and Gill-Mustang Ranch additions to the park, 44 additional sites were recorded. A third survey undertaken by Joe Hood and John Kelley in 1985 resulted in the addition of 9 more sites to the park's archaeological record.

The researcher, who has been a volunteer at Henry W. Coe State Park for thirteen years, continued the survey, beginning in 1987. State funding was no longer available for further surveys by the Resource Division of the State Park system, but an ongoing survey was imperative for the preservation and protection of cultural resources within the park.

The availability of water has been the primary factor in defining the area surveyed by the researcher. Water is a necessary resource whose availability has often determined land use in the central Diablo Range.

During the Spanish expeditions, water was also one of the main resources sought 
in the early 1800 's, as they looked for favorable sites for a second, inland chain of missions. The absence of water is frequently noted in their accounts. Camped near a spring on San Luis Creek in September 1806, Father Pedro Munoz, who accompanied Gabriel Moraga's first expedition recorded, "It is a creek well populated with alders, oaks, and other shrubs. It dries up in summer and has water only in a few pools" (Cook 1955, 260).

Father Viader, exploring for possible new mission sites in the area near San Luis Gonzaga in 1810 recorded, "This place was examined and explored and no more water was found than a few pools and one short creek, all of which together would not be adequate for a mission.." The next day they moved in a southwesterly direction. "We stopped at the foot of the range along a creek which had no more water than a few scattered pools" (Cook 1955, 259).

During the second expedition in October 1810 he wrote, "After a league we got to the arroyo of Orestimac (Orestimba Creek) ... This creek, which comes from the hills, is not flowing, nor does it contain water . . . This spot . . . would not be suitable for a mission" (Cook 1955, 260).

Water is a necessity for permanent human occupation of an area: thus the survey conducted by the researcher has been confined to areas in drainages which provide at least a seasonal flow of water. The riparian woodland, the area along watercourses and springs, was vital to life for plants and animals, including humans. Habitation sites were located near these sources of fresh water. These areas were prime hunting locations as well as gathering areas for greens, tubers, and roots (Stodder 1986, 9).

Where resources, such as water, are specifically localized, there is considerable reuse of identical places over long periods of time. This factor "tends to 'tie down' the settlement system to specific geographical areas while other areas would be occupied little 
and rarely used because of their distance from such limited and crucial resources" (Binford $1980,7)$.

Present day stream flow cannot be used to verify the availability of water in prehistoric times. However, permanent water sources can provide clues to human occupation. Along $3 \mathrm{~km}$ of Coyote creek, 12 large pools of water were found in October, 1991, even after a 6 year drought. Similarly, in December 1991, 3 large pools of water remained along a $1 \mathrm{~km}$ portion of the south fork of Orestimba Creek.

The major drainages within the park form natural passageways into the mountains. On the eastern side of the range, the south fork of Orestimba Creek drains into the San Joaquin River. It has four major tributaries within the park: Pinto, Robinson, Red, and Hartman Creeks. The north fork of Pacheco Creek drains to the south into the main fork of Pacheco Creek, which in turn flows into Monterey Bay. Its primary tributaries are Coon and Mississippi Creeks. Three branches of Coyote Creek lie within the park: the Middle, Little, and East forks. Soda Springs Creek joins with these tributaries as they drain into the main fork of Coyote Creek and eventually into San Francisco Bay (Map 3).

The drainages of Red, Orestimba, Robinson, Pinto and Hartman Creeks, the lower portion of Coyote Creek, and the unnamed drainages of Mustang Flat, Paradise Flat, and the Upper San Antonio Valley have been surveyed for sites by the researcher.

The Little, East, and Middle forks of Coyote Creek and the drainages of Coon Creek, Mississippi Creek, and the north fork of Pacheco Creek are not included in this sample. While it is certain that a survey of these drainages would proved a more complete assessment of aboriginal occupation, a thorough search for sites has not been undertaken in these areas. It seems more appropriate to present thorough surveys of some drainages than to provide incomplete information from those remaining. The archaeological investigations that were conducted in 1970, 1982, and 1985 sampled various portions of 
the park, but did not do an exhaustive search of specific areas. For that reason, only the sites from those investigations that lie within the researcher's study area have been included here.

The present survey was conducted over a period of seven years, primarily on weekends during the fall, winter and spring months. These are the most ideal times for a surface survey, as the grass cover is diminished, making identification of sites and features easier.

The survey began as an "Adopt an Area" project for State Park volunteers, a weekend during which volunteers surveyed an assigned area for cultural and environmental resources. This initial project was carried out in April, 1987. The area chosen by the researcher was a $4.5 \mathrm{~km}$ section located along the southern portion of the Red Creek drainage. In the course of the weekend, 6 archaeological sites were found. A second survey of a more northerly section of Red Creek in September 1987 resulted in the location of 3 more sites.

Other sections of Red Creek were included as the survey expanded to other portions of the park over the next six years. As time passed, the survey became more systematic, and the drainages under investigation were surveyed along their entire length, a process that required multiple visits to these areas.

The researcher sometimes worked alone, but was more often accompanied by family members, friends, or the park ranger. The method of discovery involved walking the creek beds searching for flat benches and terraces above the level of the creek. These were then inspected by a walking survey. As it became apparent that sites were often located at the confluence of small side streams, these small side drainages were inspected as well, and were followed to the point where they disappeared or became impassable. 
Surveys of the south fork of Orestimba Creek, Robinson Creek, Paradise Flat, and Mustang Flat were conducted as time, weather, and permission for access allowed. The Pinto Creek drainage was surveyed in October and December 1990, Hartman Creek in March 1991, Coyote Creek in October and December 1991, and the Upper San Antonio Valley in October 1992.

When a site was located, the data collected included locating the site on the appropriate quadrangle, determining the elevation, exposure, and slope, pacing of the midden area to determine size, identification of surface artifacts, inspection of the midden for the presence of fire-affected rock, bone fragments, or other non-artifactual constituents, measurement of the depth and diameter of housepits, measurement of the depth and diameter of milling features, and drawing a sketch of the site. Obsidian was the only artifactual material collected from the sites. Three pieces have been submitted to the state for sourcing and hydration. Currently, 31 pieces of obsidian are being held until a source of funding for similar testing can be found.

Included in this survey are 88 sites. Of these sites, 23 have received their permanent trinomial; of these, 9 were surveyed by the researcher. The remaining sites are awaiting permanent trinomials and have been assigned a temporary number, "A-" (Table 2).

Sites have been identified by their primary components. Milling stations are identified as large boulders or "an outcrop of bedrock containing one or more mortar cups, milling slicks, gyratory mills, or other features related to food grinding or crushing" (Moratto 1984, 586). A habitation site is identified by a midden, "a deposit marking a former habitation site and containing such materials as discarded artifacts, bone and shell, food refuse, charcoal, ash, rock, human remains, structural remnants, and other cultural leavings"(Moratto 1984, 592). A flake scatter is an area of "lithic refuse or debris 
produced during flaked-stone tool manufacture" (Moratto 1984, 588). These features give evidence of food procurement, food preparation, the manufacture of tools, and in the case of human remains, indicate that the inhabitants buried their dead while occupying the site, rather than returning to another village for the burial. This pattern implies that at least some of the sites described were more than temporary campsites, and may have been inhabited either permanently or intermittently for some weeks during the seasonal round of gathering (Breschini et. al., 1987, 41).

Surface surveys have been previously used to construct models which attempt to determine settlement patterns, seasonal or permanent occupation, and economic exchange systems. King and Hickman used 50 prehistoric sites in southern Santa Clara Valley in an attempt to develop a model for settlement patterns within that area. They organized the sites into three general categories: (1)occupation sites which gave evidence of diverse activities: cooking, food processing, flaked stone tool production, and human burial, (2) "smaller" (size not defined) occupation sites which gave evidence for similar activities but lacked human burials, and (3) special use sites such as milling stations and flake scatters. These sites were then put into five environmental categories: "upper canyon -- benches, terraces and ridges along the upstream portion of a canyon; canyon mouth . ., ; river bank ... ; alluvial plain . . and marsh margin" (King and Hickman in Hildebrandt and Mikkelsen 1993, 31).

Based on their finds, the researchers concluded that larger occupation sites usually occurred at the mouths of canyons and were located near fresh water and a wide range of resources. Smaller occupation sites were more variable in their location and were thought to be temporary camps used to exploit a specific resource. Special use sites were usually near large occupation sites in upper canyons (King and Hickman in Hildebrandt and Mikkelsen 1993, 31) 
Bergthold attempted to examine the King-Hickman model using 179 sites from throughout Santa Clara County. She concluded that the majority of sites did not follow the pattern of a large occupation site associated with several special use sites or temporary camps (Bergthold 1982, 211-218).

Her research determined "if all the data from all the drainages in the study area are compiled, it can been seen that all types of sites occur overwhelmingly in the riverine environment, which is in direct opposition to the King/Hickman model. . . . Their model cannot be applied indiscriminately to the entire Santa Clara Valley" (Bergthold 1982, 228233).

The weaknesses of these surface surveys are the number of questions they leave unanswered. Were all of the sites used during the same time period? How old are they? Were they used seasonally or on a permanent basis? Have some sites been destroyed by flooding or human activity? For how many years were they used? When were they first used? Last used? What is a "large" site? A "small" site? Without excavation, how can the presence of human remains be determined? Can a predictive model be constructed based on a surface survey?

In the central Diablo Range, where aboriginal use and occupation has been thought to be marginal, a surface survey can reinforce what a few archaeologists have discovered. In his report on the Menjoulet site near Los Banos Creek, William Pritchard concludes:

In general, the evidence presented in this paper leaves little doubt that Kroeber lacked the necessary demographic data to clearly establish that the west side of the San Joaquin Valley ... was "unimportant" and had "few residents" (1925: 476). The Menjoulet site was undoubtedly a major village that was occupied on a year-round basis by a substantial number of people. ... the site was probably a tribelet center (Pritchard 1970, 45). 
More recently, Mark Hylkema conducted three archaeological surveys in the central Diablo Range that resulted in "the finding of extensive prehistoric cultural deposits" (Hylkema 1992, 99).

Contrary to the belief that the uplands were desolate and lacked well developed prehistoric settlement sites, the presence of numerous human burials and the wide diversity of artifact types indicates that the uplands were intensively settled during Pacheco Complex times (2600 B.C. - A.D. 300) (Hylkema 1992, 118). 


\section{SITES WITHIN SANTA CLARA COUNTY COYOTE CREEK}

Coyote Creek begins within the park where the Little, Middle, and East Forks of Coyote Creek and Soda Springs Creek join near China Hole. Coyote Creek flows southward $8 \mathrm{~km}$. to the park's boundary. Juan Bautista De Anza passed through this drainage as he exited the Diablo Range in April 1776. Six sites have been located along this portion of the creek (Maps 4and 5).

The primary survey of Coyote Creek was conducted by the researcher in October, 1991. Large pools of water were mapped and were found to lie near or adjacent to sites. Several resources were noted which may have been utilized by an aboriginal population. These included oak, bay, sedges, blackberries, milkweed, and wild tobacco.

Further surveys were conducted intermittently during the remainder of 1991, and in 1992 and 1993. For much of its length, the creek is confined in a steep and narrow canyon. Most of the sites occupy benches or bluffs high above the stream.

A-61 is a milling station located approximately $3 \mathrm{~km}$ south of the junction of the various tributaries of Coyote Creek. It is located on a small stream-side bench on the east side of the creek. It consists of a single mortar, $11.4 \mathrm{~cm}$ in diameter by $5 \mathrm{~cm}$ in depth, located on a small stream-side boulder. A large pool of water lies less that $.3 \mathrm{~km}$ to the north.

$.3 \mathrm{~km}$ to the south lies A-15, a habitation site $\left(1696 \mathrm{~m}^{2}\right)$ that lies approximately 26 meters above the level of the stream on the east side of the creek. The midden is exceptionally dark, almost black in color. Although there was a heavy grass cover remaining on the site in October, broken ground stone tools, an acorn anvil, fire-affected 
rock, fresh water clam shells, and bone fragments were identified on the surface of the site. The site is bordered on all sides by groves of oak and bay trees. A large pool of water was located in the stream below the site.

A-87 is a milling station located $3 \mathrm{~km}$ to the south of A-15 on the west side of the creek. It is composed of a single mortar hole $15 \mathrm{~cm}$ in diameter by $4.5 \mathrm{~cm}$ in depth located on a small, circular boulder. Water is located adjacent to the site.

A-135 lies $1.1 \mathrm{~km}$ to the south on the east side of the creek. The midden area of this habitation site $\left(2153 \mathrm{~m}^{2}\right)$ varies in color from dark to light grey, and yielded broken ground stone tools and a portable hopper mortar. The site is long, 86 meters, and narrow, 19 meters, and is bounded on the east side by a steep slope. A well-defined game trail runs through the site, and a large pool of water is located nearby in the streambed.

A-138 is also a habitation site $\left(1059 \mathrm{~m}^{2}\right)$ favorably located on a stream-side bench on the west side of the creek. Site integrity has been much disturbed, as it has been bisected by a road and is also used as a parking lot for horse trailers and other vehicles. The surface collection includes broken ground stone tools, fire-affected rock, and bone fragments.

A-161 is a habitation site composed of two areas of midden located east and west of the dirt road that leads into the park from the Gilroy Hot Spring entrance. The eastern portion of midden $\left(452 \mathrm{~m}^{2}\right)$ lies adjacent to and north of an historic cabin known as the "Woodchopper's." A spring is located at the eastern boundary of the site. The site has been disturbed by historic occupation, and a dirt road has been cut through it. A concentration of ground stone tools is located near the western portion of the road cut. Another area of midden $\left(1192 \mathrm{~m}^{2}\right)$ is located approximately $30 \mathrm{~m}$ to the northwest across the Hot Springs road. One definite housepit, $2.15 \mathrm{~m}$ in diameter by $20 \mathrm{~cm}$ in depth, is located on the northernmost portion of the site. Two small depressions located 
approximately $4 \mathrm{~m}$ to the north may also be housepits. Both depressions measure approximately $1.8 \mathrm{~m}$ in diameter by $15 \mathrm{~cm}$ in depth.

A corral marks the location of A-25, an extensive area $(5781 \mathrm{~m} 2)$ of dark midden located on a bluff northeast of the confluence of Coyote Creek and Grizzly Gulch. The midden is deeper than a dirt road which cuts through the site; it shows for approximately 2.5 meters below the surface. A heavy grass cover conceals much of the surface of the site, but rodent disturbance reveals fire-affected rock, bone fragments, and ground stone tools. A portable mortar was found near the northeastern corner of the corral.

A companion site to A-25, A-132, a habitation site ( $872 \mathrm{~m} 2)$ is located on a bluff to the southeast of the confluence of Grizzly Gulch and Coyote Creek. It has been very disturbed in historic times. A road has been built through the site, and it also appears to have been leveled by a bulldozer. Glass and China fragments and scraps of lumber litter the surface. The dark midden has been revealed to a depth of approximately 2 meters by the road cut, and contains fire affected rock, bone fragments, ground stone tools, and chert and quartz flakes. A single piece of obsidian, a broken projectile point, was found in the roadcut. 


\section{THE UPPER SAN ANTONIO VALLEY}

The Upper San Antonio Valley, though lacking a major, named drainage, has important historical significance. Juan Bautista De Anza camped here on the evening of April 6, 1776. His companion and navigator, Padre Font, noted the absence of native inhabitants (Cook 1957, 135-136).

Only a portion of the Upper San Antonio Valley lies within the park. Four sites were identified here in October 1992 (Map 6).

At the northernmost boundary of the park lies A-145, an area of light grey midden $\left(1833 \mathrm{~m}^{2}\right)$ associated with a milling station. The site is located on a terrace adjacent to a seasonal, unnamed stream. Five mortars on 5 different loci are part of a large rock outcrop that occupies the northwestern portion of the site. The largest mortar is $13.5 \mathrm{~cm}$ in diameter by $16 \mathrm{~cm}$ in depth; the smallest is $10.5 \mathrm{~cm}$ in diameter by $5 \mathrm{~cm}$ in depth. More mortars may have been concealed by erosion. Flakes of chert and obsidian and tiny pebbles were found in all of the mortars as if they had been deliberately placed there.

The site is bisected by a fence, presumably defining the park's boundary. However, it was determined by Park Ranger Barry Breckling that the fence is incorrectly placed and the site lies completely within the park.

Six housepits, very eroded, were found on the southern portion of the site. There may have been more housepits, but the surface of the site has been too disturbed to determine that with any certainty. The largest housepit, which is very indistinct due to rodent activity, is $4.3 \mathrm{~m}$ in diameter and $21 \mathrm{~cm}$ in depth. Three of the housepits share similar measurements: $1.8 \mathrm{~m}$ in diameter by $21 \mathrm{~cm}$ in depth. The remaining 2 housepits are 
shallower, approximately 15 to $20 \mathrm{~cm}$ in depth. The circumference of these 2 housepits was so disturbed that their diameter could not be measured accurately.

The surface of the site yielded numerous varicolored chert flakes, 2 chert scrapers, 1 broken obsidian point, 3 obsidian flakes, a broken pestle, a rectangular piece of Haliotis shell $3.5 \mathrm{~cm}$ by $.75 \mathrm{~cm}$, burned bone fragments, and fire-affected rock. A metate and mano were found in the creekbed.

The integrity of the site has been much disturbed by rodent activity, a fence that runs through the site, adjacent San Antonio Valley Road, and by horses and cattle. A number of tree stumps on the site revealed historic logging activity as well.

A-146 lies along San Antonio Valley Road near the southernmost portion of the Upper San Antonio Valley, approximately $.5 \mathrm{~km}$ south of A-145. It consists of a milling station located on a large rock outcrop. Five mortars are located here. The largest is $16 \mathrm{~cm}$ in diameter by $8 \mathrm{~cm}$ in depth: the smallest is $12 \mathrm{~cm}$ in diameter by $3.5 \mathrm{~cm}$ in depth. An ashy grey midden area $\left(55 \mathrm{~m}^{2}\right)$ is associated with the site. A cattle feeder has been placed adjacent to the milling station, and San Antonio Valley Road is located 5m to the east. There has been much rodent disturbance as well.

A gentle drainage leads in a southeasterly direction from the Upper San Antonio Valley toward the Red Creek drainage. Two small milling stations are located in this drainage. A-147 and A-148 may have been small campsites along an aboriginal trail that passed between the Upper San Antonio Valley and Red Creek. A-147 consists of a single mortar, $12.75 \mathrm{~cm}$ in diameter by $4 \mathrm{~cm}$ in depth, and 3 possible associated cupules on a stream-side boulder. The cupules measure $3 \mathrm{~cm}$ in diameter by $3 \mathrm{~cm}$ in depth, $3 \mathrm{~cm}$ in diameter by $1.5 \mathrm{~cm}$ in depth and $2.5 \mathrm{~cm}$ in diameter by $1.5 \mathrm{~cm}$ in depth. A-148 also consists of a single mortar, $11 \mathrm{~cm}$ in diameter by $4.5 \mathrm{~cm}$ in depth, located on a blue schist boulder 
that is part of a larger rock outcrop. An area of ashy grey midden $\left(64 \mathrm{~m}^{2}\right)$ is also associated with the site. 


\section{SITES WITHIN STANISLAUS COUNTY SOUTH FORK OF ORESTIMBA CREEK}

The south fork of Orestimba Creek has its origins along the crest of the Diablo Range. As it flows northeast, it is joined by Hartman, Red, and Robinson Creeks and eleven unnamed seasonal streams. Approximately $14 \mathrm{~km}$ of the south fork lies within the park. The Orestimba drainage contains the largest number of identified sites within the survey area. Twenty-one habitations sites and 8 milling stations have been located in and along the creek, and in adjoining tributaries. (Maps 7, 8, 9, and 10)

CA-Sta-210 is a fragment of a bowl mortar, found near the headwaters of the south fork by the 1982 survey and identified by the crew as a possible trail marker. Approximately $1 \mathrm{~km}$ upstream a habitation site, CA-Sta-207, is located on the west side of the creek. It was first identified by the 1982 survey, but the discovery of human remains on the site called for a second survey which was done by Joe Hood in 1986 . The remains of at least 4 individuals were identified by Dr. Robert Jurmain of San Jose State University. The ashy grey midden area $\left(9058 \mathrm{~m}^{2}\right)$ also yielded an extensive assemblage of artifactual material including huindreds of chert and quartz flakes, a large variety of ground stone tools, a polished bone fragment, a quartz drill, unworked fragments of serpentine, and a chert knife. Two mortars are located on a rock outcrop above and adjacent to the midden area. The site lies $100 \mathrm{~m}$ north of a proposed trailhead development that will include a parking lot and restroom facilities.

CA-Sta-206, a milling station, is located less than $2 \mathrm{~km}$ north of CA-Sta-207 on the east side of the stream. The station consists of 6 mortars located on a stream-side boulder. 
CA-Sta-204 is located 2.5m upstream from CA-Sta-207. It is a habitation site $\left(1200 \mathrm{~m}^{2}\right)$ associated with a milling station containing 7 mortars. Numerous chert and quartz flakes were noted on the surface of the site. Since the 1982 survey, at least one housepit has been noted.

Possible satellite sites to CA-Sta-204, A-44, A-45, and CA-Sta 238 are clustered on stream side benches less than $.3 \mathrm{~km}$ upstream. A-44 and A-45 are habitations sites whose dark ashy midden areas measure $443 \mathrm{~m}^{2}$ and $71 \mathrm{~m}^{2}$ respectively. The midden of both sites contains fire-affected rock and bone fragments. A broken mano was found on the surface of A-44, and a game trail runs through A-45. CA-Sta-238 is a flake scatter $\left(1019 \mathrm{~m}^{2}\right)$ whose dark midden yielded several chert flakes and cores.

A-136 is a habitation site located approximately $1 \mathrm{~km}$ upstream from CA-Sta-238 on a bench on the west side of the creek at its confluence with an unnamed side stream. It is situated between 2 milling stations, CA-Sta-233, a single mortar, $14 \mathrm{~cm}$ in diameter by $5 \mathrm{~cm}$ deep, located on an outcrop of blue schist, and CA-Sta-195, containing 8 plus mortars and 4 plus cupules located on several large stream-side graywacke boulders. A heavy lichen cover prevented the detection of more features. A-136 is an area of grey midden $\left(455 \mathrm{~m}^{2}\right)$ that has the same distinctive streamside mounding noted on some sites on Robinson Creek. Two possible housepits are located here; the largest is $5.2 \mathrm{~m}$ in diameter by $15 \mathrm{~cm}$ in depth. Chert and quartz flakes and a broken white chert point were found on the site. The surface has been very disturbed by rodent activity.

No sites were located along the next $3 \mathrm{~km}$ upstream.

A-114, a habitation site, and A-115, a milling station, lie adjacent to each other approximately $.5 \mathrm{~km}$ south of the confluence of Orestimba and Red Creeks. A-114 is an area of grey midden $\left(901 \mathrm{~m}^{2}\right)$ whose surface is also mounded approximately $1 \mathrm{~m}$ above the surrounding area. The surface is so disturbed by rodent activity that it is impossible to 
determine if any housepits were located here. Chert and quartz flakes, broken ground stone tools, bone fragments and fire-affected rock were noted on the site. A-115, 3 mortars on a rock outcrop within the streambed, is located upstream within $1 \mathrm{~km}$ of A114.

A-155 is a habitation site located on a bluff above the confluence of Red and Orestimba Creeks. The grey midden area $\left(286 \mathrm{~m}^{2}\right)$ contains quartz flakes, fire-affected rock and broken ground stone tools. A partially buried hopper mortar is also located on the site. An old road cut leading up to the bluff and an uneven ground surface indicate the area has been "brushed" to remove chaparral. The integrity of the site was much disturbed by this procedure. A broken hammerstone was found protruding from an obvious bulldozer pile nearby the site.

A-140 is also a habitation site located $1.75 \mathrm{~km}$ upstream from the confluence of Red and Orestimba Creeks. The area of dark midden is located on a small terrace on the eastern edge of Paradise Flat above Orestimba Creek. No housepits were apparent on the rodent disturbed surface. The midden contains much fire-affected rock, bone fragments, chert and quartz flakes, and 2 heavily pecked hammerstones.

A milling station, CA-Sta-203, lies in the streambed approximately $1.5 \mathrm{~km}$ upstream from A-140. 21 mortars are located on a limestone outcrop. The largest of the mortars measures $21 \mathrm{~cm}$ in diameter and $19 \mathrm{~cm}$ in depth, the smallest $5 \mathrm{~cm}$ in diameter by $1 \mathrm{~cm}$ in depth. Two habitation sites, A-141 and A-144 lie .75 and 1.25km upstream. A-141 is an area of grey midden $\left(260 \mathrm{~m}^{2}\right)$ that has been much disturbed by rodent activity. A green chert core, green chert flakes, broken ground stone tools and bone fragments were found on the site.

The grey midden of A-144 $\left(611 \mathrm{~m}^{2}\right)$ contains one possible housepit $7.4 \mathrm{~m}$ in diameter by $15 \mathrm{~cm}$ in depth. Bulldozer scrapes are visible on the surface of the site. If there were 
other housepits located here, this activity probably obliterated them. The surface yielded green chert flakes, a spent green chert core, ground stone tools, bone fragments, and fireaffected rock. The site has been used for woodcutting in recent times; a number of stumps remain on and adjacent to it.

At this point the Orestimba flows through private property, the Rooster Comb Ranch, for approximately $2 \mathrm{~km}$. Several large habitation sites have been located here, but are not included in this sample as they lie outside the park.

Eight sites lie within an area of slightly more than $1 \mathrm{~km}$ north and east of the Rooster Comb Ranch. A-94 and A-95 are habitation sites located on stream-side terraces on the west side of Orestimba Creek. Their dark ashy midden areas measure $1462 \mathrm{~m}^{2}$ and $2312 \mathrm{~m}^{2}$ respectively; chert and quartz flakes and intact and broken ground stone tools are visible on both sites. A unique artifact, a small, breast shaped rock $6 \mathrm{~cm}$ in length by $5 \mathrm{~cm}$ in diameter, was found on A-95. Both sites are disturbed by rodent activity, and A-95 has been bisected by a dirt road.

A-96 is a habitation site $\left(1948 \mathrm{~m}^{2}\right)$ located on a bluff approximately $.4 \mathrm{~km}$ east and $70 \mathrm{~m}$ above Orestimba Creek. Sixteen housepits are located in a large open area surrounded by chamise and thornbush. They are in two groups; one contains 9 housepits, the other contains 6 . The housepits vary in diameter from $3.07 \mathrm{~m}$ to $1.23 \mathrm{~m}$ and in depth from $30 \mathrm{~cm}$ to $11.5 \mathrm{~cm}$ A single housepit, $2.76 \mathrm{~m}$ in diameter and $20.5 \mathrm{~cm}$ in depth, lies isolated from the others on the eastern boundary of the site. The housepits are placed randomly on the site and lack the semi-circular pattern noted on other sites in this area. They are also smaller in diameter. Along the edge of 6 of the housepits, lies a piece of blue schist, each approximately $20 \mathrm{~cm}$ in diameter. These stones appear to have been placed deliberately. Broken ground stone tools and a broken portable slab mortar were located on the surface of the site. The soil on the site is red loam, and ashy midden is 
lacking, except in the central area of the site near the broken mortar. Iron oxide in the soil may have consumed the oryanic portions of the midden (Joe Hood, personal communication, October 1990).

Two sites lie east of A-96 along unnamed seasonal drainages. A-102 is an isolate portable hopper mortar that was found lying under an oak tree along an unnamed drainage $1.6 \mathrm{~km}$ east of A-96. A thorough search of the surrounding area failed to reveal any midden areas. A-101 is a habitation site $\left(465 \mathrm{~m}^{2}\right) .3 \mathrm{~km}$ downstream from a sulfur spring. The site is located along an unnamed drainage $1 \mathrm{~km}$ northeast of A-96. The surface collection included a red sandstone acorn anvil, broken ground stone tools and quartz flakes.

A-88, A-92, and A-93 are a complex of sites located approximately .6km north of A95.

A-88 is a habitation site $\left(660 \mathrm{~m}^{2}\right)$ situated on a stream-side terrace approximately $.1 \mathrm{~km}$. west of Orestimba Creek along an unnamed side stream. Seventeen housepits have been identified on the surface of the site. The largest housepit, which measures $8 \mathrm{~m}$ in diameter and $60 \mathrm{~cm}$ in depth, may have been used for ceremonial purposes. The berm surrounding it is still intact and appears to be well preserved. It is raised approximately $40 \mathrm{~cm}$ above the surrounding area.

The housepits are placed on the site in a slightly semicircular pattern. The next largest housepits (there are 2 of them) are $6.15 \mathrm{~m}$ in diameter. One measures $30 \mathrm{~cm}$ in depth, the other $35 \mathrm{~cm}$ in depth. The smallest housepit measures $2.76 \mathrm{~m}$ in diameter and $18 \mathrm{~cm}$ in depth. Three small depressions are also located on the site. One of them measures $1.84 \mathrm{~m}$ in diameter, the other two each measure $1.07 \mathrm{~m}$ in diameter. They are 20 , 6 , and $8 \mathrm{~cm}$ in depth. Two of them lie along the southwestern boundary of the midden where there is considerable rodent disturbance. The other lies between 3 housepits. The 
possible ceremonial housepit lies at the northern boundary of the midden; all the other housepits lie south of it. The integrity of the site is being destroyed very rapidly by rodent activity.

A hopper mortar whose wide, $7.6 \mathrm{~cm}$, but shallow, $2.5 \mathrm{~cm}$, mortar hole is associated with a slick, $12 \mathrm{~cm}$ long and $2.5 \mathrm{~cm}$ in depth, was found on the site along with various broken tools. The housepits are located east of a dirt road that bisects the site, though approximately one-third of the midden area lies to the west of it.

A-92 and A-93 are located west of A-88 along the small unnamed side drainage. A92 is an area of midden $\left(242 \mathrm{~m}^{2}\right)$ associated with a milling station. It is located $3 \mathrm{~km}$ west of A-88. It consists of 2 stream-side boulders, 1 containing 3 mortars, the other containing 1. A-93, an area of dark ashy midden $\left(55 \mathrm{~m}^{2}\right)$ containing fire affected rock, lies $.2 \mathrm{~km}$ upstream from A-92.

CA-Sta-201 is a milling station located in the streambed of Orestimba Creek $1.6 \mathrm{~km}$ upstream from A-88. It consists of 18 mortars and 3 plus cupules on 6 limestone boulders. The surveyor noted that the cupules are very shallow and wide, $5-6 \mathrm{~cm}$ in diameter and less than $.5 \mathrm{~cm}$ in depth, and may have been incipient mortars or acorn anvils. The largest mortar measures $15 \mathrm{~cm}$ in diameter and $17 \mathrm{~cm}$ in depth, the smallest $9 \mathrm{~cm}$ in diameter and $3 \mathrm{~cm}$ in depth.

A-99 and A-128 are located approximately .5km upstream from the confluence of Robinson and Orestimba Creeks. A-99, a habitation site $\left(325 \mathrm{~m}^{2}\right)$, is located on a streamside bench overlooking Orestimba Creek. A red sandstone acorn anvil and various broken ground stone tools were located on the surface of the light grey midden. A dirt road has been constructed through the site.

A-128 lies northwest of A-99 on a small terrace. The grey midden area $\left(616 \mathrm{~m}^{2}\right)$ lies $1-1.5 \mathrm{~m}$ above the surrounding soil. Two distinct housepits are visible on the site; there 
are 3 other depressions that may also be very eroded housepits. The largest housepit is $6.2 \mathrm{~m}$ in diameter and $15 \mathrm{~cm}$ in depth; the smallest is $2.5 \mathrm{~m}$ in diameter by $15 \mathrm{~cm}$ in depth. The site has been very disturbed by rodent activity. A single piece of obsidian, broken ground stone tools, and bone fragments were found on the site.

A semi-portable hopper mortar, CA-Sta-202, was found on the southern bank of Orestimba Creek by the 1982 survey. It lies directly north of A-35, a habitation site $\left(4147 \mathrm{~m}^{2}\right)$ on a stream-side terrace containing 22 possible housepits that are in various stages of erosion. Four small, very eroded housepits are located on the western edge of the site, along Orestimba Creek. One measures $4.2 \mathrm{~m}$ in diameter by $10 \mathrm{~cm}$ in depth and another measures $3 \mathrm{~m}$ in diameter by $10 \mathrm{~cm}$ in depth. It is possible these very eroded housepits indicate an area that was abandoned in favor of the group of housepits located along an unnamed side stream on the southern edge of the terrace. Eighteen possible housepits are located here. There may have been more housepits along the creek's edge, but the area has been undercut by the stream. The largest housepit in this group, possibly a ceremonial housepit, is $9.5 \mathrm{~m}$ in diameter by $75 \mathrm{~cm}$ in depth. It lies to the west of all the other housepits. The other housepits are arranged in 2 rows in a slightly semi-circular pattern along the streambank. The largest of these is $5 \mathrm{~m}$ in diameter by $75 \mathrm{~cm}$ in depth. A large, flat open area separates the housepits adjacent to Orestimba Creek from those located along the small side-stream. The midden contains a large assortment of groundstone tools, intact and broken, chert and quartz flakes, and fire-affected rock.

A-100 and A-37 are habitation sites that lie only partially within the park; both are located along the park's eastern boundary. A-100, an area of dark midden $\left(363 \mathrm{~m}^{2}\right)$ littered with ground stone tools, is located on a stream-side bench above Orestimba Creek. A dirt road passes through the site and a fence bisects it. 
A-37 is an area of dark ashy midden $\left(207 \mathrm{~m}^{2}\right)$ located on a hillside bench $.3 \mathrm{~km}$ steeply uphill to the north of A-100. Human remains were discovered here by park neighbor Stan Azevedo when he was digging postholes for the boundary fence. According to Mr. Azevedo, the bones were identified at U.C. Berkeley. This information was related to Park Ranger Jim Layton in 1984 (Jim Layton, personal communication, December 1987). Perhaps, because of its inaccessibility, there is still a very large scattering of ground stone tools on the site. The area surrounding the site is not only very steep, but it is covered with a dense growth of chaparral which made identification of artifacts and midden boundaries very difficult. Rodent activity has also damaged the site. 


\section{HARTMAN CREEK}

Hartman Creek has its origins on the eastern slopes of the ridgeline which forms the crest of the Diablo Range. It drops steeply from twin streamlets on chaparral covered hillsides to flow for approximately $7 \mathrm{~km}$ east to join with the south fork of Orestimba Creek.

The canyon through which it flows is narrow for much of its length, widening only near its confluence with Orestimba Creek. The area near the confluence was the site of a stock pond which was removed by the State Park, and if there was any prehistoric occupation here, all traces of it have been destroyed.

Four sites have been identified along the Hartman drainage, and a fifth lies on a ridgeline above it (Map 11). The drainage was surveyed by the researcher in April 1991 and April 1993.

A-154 is a habitation site $\left(147 \mathrm{~m}^{2}\right)$ that lies approximately $1.2 \mathrm{~km}$ upstream from the Hartman-Orestimba confluence. The ashy grey midden is distinctly mounded above the surrounding area and contains fire-affected rock, bone fragments, a pestle, acorn anvil, and other broken ground stone tools. The surface has been much disturbed by rodent activity.

A-129 is also a habitation site $\left(488 \mathrm{~m}^{2}\right)$ located $2.7 \mathrm{~km}$ upstream from A-154 along the southern branch of Hartman Creek. The dark ashy midden contains bone fragments, but a heavy grass cover prevented the identification of other artifactual material at the time it was surveyed.

A-130 and A-131 are located approximately .5km further upstream from A-129. A130 is another habitation site $\left(267 \mathrm{~m}^{2}\right)$ whose dark midden is divided between 2 stream- 
side benches. Again, there is an absence of artifacts, but the midden contains considerable fire-affected rock. A distinctive feature of the site is its proximity to a sulfur spring $30 \mathrm{~m}$ downstream. A-131 is a milling station containing 4 mortars. It is located on the west bank of the creek $10 \mathrm{~m}$ west of A-130.

The largest site in the Hartman drainage is not located along the stream, but on the ridgeline west of the it approximately $1.75 \mathrm{~km}$ upstream from the Hartman-Orestimba confluence. A-133 is a habitation site containing a single housepit whose surrounding berm is still intact. The housepit measures $5.9 \mathrm{~m}$ in diameter by $77 \mathrm{~cm}$ in depth. Heavy grass cover at the time of the survey made the determination of midden size difficult; the surface is very uneven, and there is a possibility that there are more housepits on the sites that were hidden by the grass. The midden, which is very light in color, measures approximately $1120 \mathrm{~m}^{2}$. Quartz flakes were the only visible artifactual constituent. A distinct trail, perhaps aboriginal, but now defined as a game trail, leads from Hartman Creek to and through A-133 and then continues beyond the site to the northwest over a saddle and down a small drainage $2 \mathrm{~km}$ to Red Creek. 


\section{MUSTANG FLAT}

Mustang Flat is a large, flat open area of grassland and oak woodland on the east side of the Orestimba drainage. The gentle terrain invited historic as well as prehistoric use. Tony Aguila, one of Frank Latta's informants, recalled rounding up wild mustangs here in the late 1800's (Latta 1977, 137). In addition, Mustang Flat was an overnight campsite for Joaquin Murietta's wild horse gangs (Latta 1980, 433).

Three habitation sites and 2 milling stations, 1 with associated cupules and incised petroglyphs, are located on Mustang Flat (Map 9). CA-Sta-234 is a habitation site $\left(153 \mathrm{~m}^{2}\right)$ located on a knoll above an unnamed seasonal stream approximately $.5 \mathrm{~km}$ east of Orestimba Road. No housepits are visible on the site, but the surface has been very disturbed by rodent and wild pig activity. Green chert flakes and cores, a projectile point of Monterey banded chert, clam shell fragments, 2 obsidian tool fragments and a single unworked obsidian flake were noted on the surface of the site. Both obsidian tool fragments originated from Bodie Hills; the single obsidian flake came from the Napa Valley. A lower right portion of a human mandible with 3 teeth in place was also found on the site.

CA-Sta-232 is a habitation site $\left(6861 \mathrm{~m}^{2}\right)$ located on a broad terrace between 2 unnamed side streams. It lies approximately $.2 \mathrm{~km}$ southeast of CA-Sta-234. This site was the location of historic as well as prehistoric activity. A hand forged iron bucket handle, a barrel hoop, square nails and some fragments of thick, opalescent bottle glass are clustered around a pile of stones, probably the remains of a well, on the northern portion of the site. 
Presumably, this locale is where Tony Aguila gathered wild mustangs, as Mustang Spring is located on the southwestern corner of the site. This may have been the Murietta gang's campsite as well, as the spring supplies a reliable source of water all year round.

Seven housepits and possibly 5 more indefinite housepits are located on the site. All are very shallow and badly eroded. The largest measures almost $10 \mathrm{~m}$ in diameter and $60 \mathrm{~cm}$ in depth. The berm surrounding the pit is barely discernible. Originally, this was the only housepit included in the site survey. The site was visited a number of times before additional housepits were discovered. This discovery was made late in winter and was aided by a lack of tall grass cover at this time of the year. Six distinct housepits are grouped in a slight semicircle on the southern portion of the site, 1 to the west of the largest housepit, 5 to the east of it. More housepits may lie to the east also, but this area is very rodent disturbed. These smaller housepits vary in diameter from $3.7 \mathrm{~m}$ to $2.2 \mathrm{~m}$ and in depth from 30 to $15 \mathrm{~cm}$. Two other very eroded housepits lie behind and to the south of the others. A small area of very dark, but very rodent disturbed midden on the northeastern portion of the site contains 3 indistinct housepits. There may have been more, but the area is too disturbed to identify any features with certainty. In the 7 years since the site was first discovered, the surface of the site, and especially the housepits, have deteriorated due to rodent disturbance.

The site has an extensive collection of artifactual material including whole and broken manos, pestles, and hammerstones. Several chert and quartz flake scatters are visible on the surface. Also found here were a portable bowl mortar, a quartz crystal approximately $4 \mathrm{~cm}$ in length, and an obsidian projectile point fragment. The point fragment was sourced to Queen, east of Mono Lake in Mono County. A human phalanx and a right lateral incisor were found in the largest housepit. 
A-113 is a habitation site $\left(792 \mathrm{~m}^{2}\right)$ that is also located on a small terrace bordered on either side by unnamed seasonal streams. It lies $.5 \mathrm{~km}$ to the north of CA-Sta- 232 . There are depressions on the site that may have been housepits, but rodent activity has disturbed the surface to such an extent that it is impossible to determine housepit presence with any certainty. The surface collection included broken ground stone tools, bone fragments, a small portion of a deer antler tine, fire-affected rock and chert and quartz flakes.

CA-Sta-218 is a milling station containing 14 plus mortars, 40 plus cupules, and 2 possible incised petroglyphs of an unknown style on a large boulder located on the side of a shall canyon. One possible quartz core and a small round pecked stone were found on the site. It is located $.5 \mathrm{~km}$ southwest of A-113, .2km northwest of CA-Sta-232, and $.4 \mathrm{~km}$ northwest of CA-Sta-234.

CA-Sta-231 is a milling station containing 2 mortars on a single boulder that is part of a blue schist outcrop. It is located midway between CA-Sta-232 and A-113. 


\section{RED CREEK}

The headwaters of Red Creek are located north of the park near the Upper San Antonio Valley. The creek flows for $16 \mathrm{~km}$ to the southeast where it joins the south fork of Orestimba Creek. It is considered a seasonal stream, but during years of adequate rainfall deep pools of water remain in the streambed throughout the year. In addition, a number of springs are found along its course which flow all year. Ten habitation sites, 7 milling stations, and 1 flake scatter have been identified along Red Creek (Maps 6, 9, 11 , 12 , and 13).

Sites along the eastern portion of Red Creek, near its confluence with Orestimba Creek, occur with almost predictable regularity. The creek bed is wide for approximately $4 \mathrm{~km}$ with appealing stream-side terraces that invited human habitation.

Five habitation sites and a flake scatter have been located here at intervals varying between .5 and $1 \mathrm{~km}$. CA-Sta-252 is a habitation site $\left(1112 \mathrm{~m}^{2}\right)$ located on a stream-side bench on the north side of the creek approximately $.75 \mathrm{~km}$ from the Orestimba confluence. A milling station composed of a single mortar rests on the bedrock that is part of the streambank. A number of artifacts were observed on the site: green Franciscan chert flakes, quartz flakes, a Monterey banded chert point, manos, pestles, an acorn anvil, 3 hammerstones, one of which is made of granite, and other broken ground stone tools.

CA-Sta-253 is located on a southern stream-side bench approximately $1 \mathrm{~km}$ upstream from CA-Sta-252. Assorted broken ground stone tools, 2 partially buried hopper mortars, and 1 pestle were identifed on the surface of this habitation site $\left(680 \mathrm{~m}^{2}\right)$. 
CA-Sta-258 is a flake scatter $\left(98 \mathrm{~m}^{2}\right)$ located on a stream-side bench approximately $.3 \mathrm{~km}$. upstream from CA-Sta-253 on the north side of the creek. Green Franciscan chert flakes and a single obsidian flake were found on the surface of the site.

Large rock outcroppings, some of which have fissures containing crystals, dominate CA-Sta-254. This habitation site is located on the south side of the creek approximately $1 \mathrm{~km}$ northwest of CA-Sta-253. The surface of the dark midden area $\left(471 \mathrm{~m}^{2}\right)$ has been very disturbed by wild pig activity. Three green Franciscan chert cores and chert flakes, a pestle, and a human molar and part of a femur were found here.

A-75, a habitation site $\left(247 \mathrm{~m}^{2}\right)$, lies approximately $1 \mathrm{~km}$ upstream from CA-Sta-254 on the south side of the creek. Four indistinct depressions may have been housepits; two of the depressions have been undercut by the stream. The dark midden yielded green Franciscan chert flakes and a green chert core, broken ground stone tools, and a green schist teardrop shaped pestle. Cattle grazing and flooding have disturbed the integrity of the site.

Approximately . $75 \mathrm{~km}$ upstream lies a-83, also on the south side of the stream. It consists of an area of ashy midden adjacent to a milling station. Five mortars and 1 cupule are located in a large boulder situated on the edge of the creek. A small oak tree growing from the top of the boulder may conceal a sixth molar. A heavily pecked hammerstone rested on the top of the boulder for many years.

Upstream from A-83, the canyon becomes very narrow for approximately $2 \mathrm{~km}$ When it widens again, a cluster of 3 habitation sites, all containing housepits, and a single milling station are located along within a $.6 \mathrm{~km}$ stretch of the creek.

The first site to be encountered is CA-Sta-255 located on a stream-side terrace on the south side of the creek. A large grove of grey pine trees covers the entire site, but they are undoubtedly too young to have been in existence when the site was occupied 
(average life-span is only 60-80 years) (Arno 1973, 1). The light grey midden $\left(1499 \mathrm{~m}^{2}\right.$ ) contains 12 housepits, the largest $4.3 \mathrm{~m}$ in diameter, the smallest $2 \mathrm{~m}$ in diameter. The depth of all the housepits varies from 30 to $80 \mathrm{~cm}$. Green Franciscan chert flakes, broken ground stone tools and an acorn anvil were located on the surface of the site.

A milling station, A-105, with an associated midden is located adjacent to and northwest of the site along an unnamed side stream. The midden area $\left(4288 \mathrm{~m}^{2}\right)$ runs upstream for approximately $30 \mathrm{~m}$. A hammerstone and other broken tools are located on the midden surface. A large boulder contains at least 2 mortars, however a heavy silt deposit may conceal others. At least 1 spring is located in the streambed nearby.

CA-Sta-256 and 257 are located less than $.5 \mathrm{~km}$ upstream on streamside terraces on the northeast side of the creek. They are less than .1km apart on stream-side terraces which are bordered by small unnamed seasonal streamlets. The midden of both sites is dark and ashy. CA-Sta-256 $\left(855 \mathrm{~m}^{2}\right)$ contains 8 housepits that vary in diameter from $4 \mathrm{~m}$ to $2.8 \mathrm{~m}$ and from 30 to $15 \mathrm{~cm}$ in depth. CA-Sta-257 $\left(462 \mathrm{~m}^{2}\right)$ contains 6 houspits ranging in diameter from $3.5 \mathrm{~m}$ to $3 \mathrm{~m}$ and in depth from 60 to $15 \mathrm{~cm}$. Green Franciscan chert flakes, quartz flakes, and broken ground stone tools litter the surface of the sites. The housepits are being destroyed by wild pig and rodent activity.

These three sites are the first along Red Creek to exhibit definite housepits. The exception is A-75 $3 \mathrm{~km}$ downstream which contains only indefinite depressions. The 3 sites are also located near the jeep trail which leads over a saddle in the Robinson drainage where the habitation sites also contain housepits. The jeep trail may have followed an aboriginal trail leading from the Robinson drainage into the Red Creek drainage.

CA-Sta-259 was probably also a habitation site. Located less than .1km upstream from CA-Sta-257 on the opposite side of the creek, it has been reduced by a bulldozer blade to a pile of broken tools and an area of dark midden $\left(549 \mathrm{~m}^{2}\right)$. 
Red Creek narrows once again at this point. Two milling stations have been identifed along this portion of the creek. A-36 is located approximately $2 \mathrm{~km}$ upstream from CA-Sta-259. Five mortars are located on a large boulder on the west side of the creek. Their measurements were not noted. A-6 is located $1 \mathrm{~km}$ upstream from A-36. Eight mortars are located on a large boulder on the east side of the creek. The largest mortar measures $15 \mathrm{~cm}$ in diameter by $14 \mathrm{~cm}$ in depth; the smallest is $10 \mathrm{~cm}$ in diameter by $6 \mathrm{~cm}$ in depth. Two areas of dark soil in the area of the milling stations may represent midden, but artifactual and non artifactual materials are absent from both areas.

At this point Red Creek branches into a number of small tributaries along the south facing slope which separates the Red Creek drainage from the Upper San Antonio Valley. One of the tributaries leads northwest for approximately $2.3 \mathrm{~km}$, providing a natural passageway into the Upper San Antonio Valley. Four sites are located along this tributary; 2 milling stations and 2 small habitation sites.

A-152 is a small area of midden $\left(16 \mathrm{~m}^{2}\right)$ located approximately $.5 \mathrm{~km}$ beyond the point where Red Creek separates into tributaries. The midden contains bone fragments and fire-affected rock.

Upstream $4.5 \mathrm{~km}$ is A-151, a milling station consisting of 7 mortars on a streamside rock outcrop. The largest mortar is $13.3 \mathrm{~cm}$ in diameter by $8.5 \mathrm{~cm}$ in depth; the smallest is $10.4 \mathrm{~cm}$ in diameter by $4 \mathrm{~cm}$ in depth. A-150, another milling station, is only $.1 \mathrm{~km}$ upstream and consists of a single mortar on a stream side boulder. The mortar measures $11 \mathrm{~cm}$ in diameter by $3 \mathrm{~cm}$ in depth.

A-149 is located $1 \mathrm{~km}$ upstream near the ridgeline that marks the crest of the Diablo Range. It is an area of grey midden $\left(121 \mathrm{~m}^{2}\right)$ adjacent to a sulfur spring. Another sulfur spring is located approximately $46 \mathrm{~m}$ downstream. One pestle and much fire-affected rock was found upon the site. A rockslide appears to have covered part of the site, and 2 small 
handmade dams are located just upstream from the midden area. One of the dams is built of rock, the other of concrete.

These 4 small sites, located along this steep and narrow drainage, are similar to sites A-147 and A-148 located across the crest of the Diablo Range in the southeastern corner of Upper San Antonio Valley. They may have been campsites along an aboriginal trail leading from Red Creek to areas to the north and west.

A-118 is located along a small eastern branching tributary. It consists of a milling station located in a rock outcrop along the edge of the stream. The outcrop contains mortars; the largest measures $15 \mathrm{~cm}$ in diameter by $7.5 \mathrm{~cm}$ in depth and the smallest $9 \mathrm{~cm}$ in diameter by $2.5 \mathrm{~cm}$ in depth. A path runs adjacent to the site. 


\section{PARADISE FLAT}

Paradise Flat is a large area of grassland located east of the Red Creek drainage. Paradise Flat was identified by Frank Latta as one of Joaquin Murietta's horse camps (Latta1980, 433). A landing strip was constructed here for use by the cattle ranchers. Red Creek Road runs parallel to the landing strip. This historic occupation undoubtedly affected the integrity of the prehistoric sites located here (Maps 8. 9. and 11).

Three sites are located adjacent to the landing strip. A-1 19 is located near the northernmost portion, CA-Sta-208 near its middle, and A-120 at its southernmost point.

A-1 19 is a habitation site whose grey midden area $\left(1194 \mathrm{~m}^{2}\right)$ has been disturbed by the construction of Red Creek Road, which runs through it, a corral which has been constructed on it, rodent activity, and the landing strip which lies only $10 \mathrm{~m}$ west of it. The midden surface contains broken ground stone tools and bone fragments.

CA-Sta-208 is identifed as a small $\left(200 \mathrm{~m}^{2}\right)$ hunting site whose integrity has been disturbed by Red Creek Road and the landing strip. A chert flake tool and a projectile point fragment were found here.

A-120 is a habitation site whose midden area $\left(1665 \mathrm{~m}^{2}\right)$ contains bone fragments, chert and quartz flakes, broken ground stone tools, and a green schist hammerstone. The site has also been disturbed by the construction of Red Creek Road, which runs through it. Two discarded tractor disks were found on the site. It is very possible that this entire area was plowed and planted to grain, destroying any surface features.

A-139, an isolate projectile point of Monterey banded chert, was found on the west side of Paradise Flat by a game trail which runs adjacent to a patch of chamise. 
A-103 lies to the north of Paradise Flat within .1km of Paradise Lake, a spring-fed stock pond. The dark ashy midden area $\left(1257 \mathrm{~m}^{2}\right)$ has been disturbed by a road that has been constructed to the lake. Broken clay pigeons, used in target practice, litter its surface. A bowl metate, a red sandstone acorn anvil, and various ground stone tools were found on the site. 


\section{ROBINSON CREEK}

Robinson Creek originates on the slopes of a ridgeline which runs east of and parallel to the Red Creek drainage. The creek flows for approximately $8 \mathrm{~km}$. in an easterly direction to the point where it joins with the south fork of Orestimba Creek. Robinson Creek is narrow for much of its length, widening only at the Pinto Creek confluence and again at its junction with Orestimba Creek. This may account for the small number of sites found here (Maps 10 and 14).

A-104 is the only site which has been identified near the creek's origins. It is located on a stream-side bench on the northwest side of the creek, approximately $1.5 \mathrm{~km}$ from the creek's onset. Two rows of housepits, 4 definite and 2 that are possible, are visible on the light midden $\left(632 \mathrm{~m}^{2}\right)$.

The largest housepit is $3 \mathrm{~m}$ in diameter by $38 \mathrm{~cm}$ in depth. Rodent disturbance has made it difficult to determine if there are any other housepits. A uniface mano and broken ground stone tools were found on the surface. A unique feature of the site is a definite mounding of the midden, almost 1 meter high, on the stream-side. It appears to have been deliberately constructed.

Six other sites have been identified along the Robinson drainage; all are located within approximately $1 \mathrm{~km}$ of its confluence with Orestimba Creek. One is a milling station; the other 5 are habitation sites, 1 of which is associated with 3 milling stations.

A-1 is a milling station situated on a large graywacke boulder located in a grassy area above Robinson Falls. It consists of 3 mortars and 3 cupules. It lies $.3 \mathrm{~km}$ upstream from A-107, a habitation site located on a bluff above the creek. Its midden area $\left(792 \mathrm{~m}^{2}\right)$ is bisected by Robinson Creek Road. Two housepits are visible on the site; road 
construction probably destroyed any others that may have existed here. Each of the housepits is $3.38 \mathrm{~m}$ in diameter. The depth of each varies: one is 31 to $46 \mathrm{~cm}$, the other from 31 to $77 \mathrm{~cm}$. The light colored midden surface yielded green Franciscan chert flakes, quartz flakes, broken ground stone tools, fire-affected rock and bone fragments. The site has the same deliberate stream-side mounding as does site A-104.

A-91 is a habitation site on the south side of the creek. It is associated with 3 milling stations located in the streambed. One of these features contains 3 mortars; 2 others each contain 2 mortars. The midden area $\left(2356 \mathrm{~m}^{2}\right)$ occupies a stream-side terrace on the south side of the creek approximately $.75 \mathrm{~km}$ from its confluence with Orestimba Creek. The surface yielded a hammerstone, a mano, numerous broken ground stone tools and fireaffected rock. No housepits were noted on the site. According to Gary Davenport (personal communication, Oct. 1992), the original headquarters for the Gill-Mustang Ranch was located near here a number of years ago. A small rock foundation and a granite ware coffee pot are all that remain to give testimony to their existence.

A-89 (840m2) occupies a stream-side terrace on the north side of Robinson Creek approximately $.4 \mathrm{~km}$ downstream from A-91. A sulfur spring is located in the creek adjacent to the site. Nine housepits are visible here. The largest measures $7 \mathrm{~m}$ in diameter by $60 \mathrm{~cm}$ in depth. The smallest is $3.8 \mathrm{~m}$ in diameter by $5 \mathrm{~cm}$ in depth. The housepits are arranged in 2 semicircular rows in contrast to those found on Red Creek that appear to be placed at random on the sites. A single Olivella shell bead was found in the largest housepit. Various ground stone tools are on the surface of the site.

The two remaining sites, A-97 and A-98, are located at the confluence of Robinson and Orestimba Creeks. A-97 is on the south side of the confluence, A-98 is on the north side. 
A-98 is a habitation site $\left(1772 \mathrm{~m}^{2}\right)$ featuring a single housepit. This feature is $4.3 \mathrm{~m}$ in diameter by $30.5 \mathrm{~cm}$ in depth. There are other depressions on the site that may have been housepits, but road construction and other bulldozer activity including "brushing" to remove the chaparral on the site to increase the grass yield for cattle grazing, have done extensive damage to the surface. Some broken ground stone tools and a single obsidian flake were found here.

A-97 is also a habitation site whose midden area $\left(1414 \mathrm{~m}^{2}\right)$ has been disturbed by several road cuts. The site is located on a small bluff above the confluence; the midden runs downhill to the stream. Broken ground stone tools litter the surface of the site. 


\section{PINTO CREEK}

Pinto Creek has its source in the steep chaparral clad slopes south of Mt. Stakes. Four sites have been identified along its length (Map 14).

The largest site, A-117, is a habitation site located at the confluence of Pinto and Robinson Creeks. It consists of 2 areas of ashy grey midden located on stream side terraces. The lower level measures $365 \mathrm{~m}^{2}$ and contains 8 distinct housepits and a possible indistinct ninth housepit. The largest of these measures $4.6 \mathrm{~m}$ in diameter by $60 \mathrm{~cm}$ in depth; the smallest is $2.5 \mathrm{~m}$ in diameter and $15 \mathrm{~cm}$ in depth. A shallow hopper mortar is situated in one of the housepits. The housepits are directly adjacent to the Pinto Creek streambed, and additional housepits may have been eroded away by seasonal flooding. A number of grey pines are growing on the small terrace on which the housepits are located; some are growing in the housepits.

The second level of the site is an open terrace lying approximately $3 \mathrm{~m}$ above that which contains the houspits. The midden area measures $314 \mathrm{~m}^{2}$. Human remains were found here: a lateral incisor and a portion of cranium approximately $6 \mathrm{~cm}$ by $6 \mathrm{~cm}$.

Both midden areas contain broken ground stone tools, fire-affected rock, and bone fragments. Both have been disturbed by rodent activity. The former foreman of a neighboring ranch provided the information as to the location of this site, and described it as a good place to collect artifacts (Dick Carlos, personal communication, May 30, 1990).

A-125, a milling station, is situated $.3 \mathrm{~km}$ above A-1 17 on a hillside overlooking the confluence of Pinto Creek and an unnamed side stream. The site consists of a large boulder containing 6 mortars. The largest diameter is $17.5 \mathrm{~cm}$; the smallest $10 \mathrm{~cm}$. The depth varies from $15 \mathrm{~cm}$ to $4 \mathrm{~cm}$. A broken pestle was found next to the milling station. 
A small habitation site $\left(328 \mathrm{~m}^{2}\right)$, A-126, lies on a hillside bench above A-125. The dark, ashy midden area contains green and white chert flakes and broken ground stone tools. The site is much disturbed by rodent activity.

Another small habitation site, A-127, lies $.5 \mathrm{~km}$ beyond and uphill from A-126. The dark midden area $\left(63 \mathrm{~m}^{2}\right)$ occupies a small stream-side bench. The surface collection included ground stone tools, bone fragments, and a small, broken piece of Haliotis shell. 


\section{CHAPTER FOUR}

\section{SUMMARY AND CONCLUSIONS}

included in the survey are 57 habitation sites, 27 milling stations, 2 flake scatters, 2 locales with hopper mortars, 1 bowl mortar fragment, 1 isolate projectile point, and 1 hunting site (Table 5).

The majority of all sites are located on streamside benches, $45 \%$, or streamside terraces, $19 \%$. The remaining sites are variously located: $6 \%$ canyon bottom, $6 \%$ streamside, $5 \%$ ridge or ridge top, $1 \%$ valley bottom, $2 \%$ bluff, $2 \%$ streambed, $2 \%$ hillside, $2 \%$ canyon, $2 \%$ canyon side, $2 \%$ knoww top, $3 \%$ flat land (Table 3 ).

Oak woodland is identified as the vegetation community on $75 \%$ of the sites. The remainder are within oak woodland/grassland, 11\%, oak woodland/riparian, 7\%, oak woodland/chaparral, $3 \%$, grassland, $1 \%$, and chaparral, $1 \%$ (Table 3 ).

Housepits are located on $30 \%$ of the habitation sites. Possible housepits are located on 3 other sites (Table 4). All are in various stages of erosion resulting from natural siltation or from rodent or human disturbance.

Midden areas vary in size from less than $500 \mathrm{~m}^{2}, 38 \%, 501 \mathrm{~m}^{2}$ to $1000 \mathrm{~m}^{2}, 23 \%$, $1001 \mathrm{~m}^{2}$ to $1500 \mathrm{~m}^{2}, 16 \%, 1501 \mathrm{~m}^{2}$ to $2000 \mathrm{~m}^{2}, 11 \%$, and $2001 \mathrm{~m}^{2}$ to $2500 \mathrm{~m}^{2} 5 \%$. The four largest sites, A-25, $5781 \mathrm{~m}^{2}, \mathrm{~A}-35,4147 \mathrm{~m}^{2}, \mathrm{CA}-\mathrm{Sta}-232,6861 \mathrm{~m}^{2}$, and CA-Sta-207, $9058 \mathrm{~m}^{2}$, comprise $5 \%$ of the midden locales (Table 5).

The largest number of sites, $27 \%$, are located between $336 \mathrm{~m}$ and $366 \mathrm{~m} .19 \%$ are located below $305 \mathrm{~m}, 9 \%$ between $305 \mathrm{~m}$ and $335 \mathrm{~m}, 18 \%$ between $366 \mathrm{~m}$ and $396 \mathrm{~m}, 14 \%$ between $396 \mathrm{~m}$ and $427 \mathrm{~m}$, and $12 \%$ above $427 \mathrm{~m}$ (Table 3 ). With the exception of A-37, located on a hillside above the south fork of Orestimba Creek, the sites with the highest 
elevations are located in the Upper San Antonio Valley and along the northernmost tributariesof Red Creek.

Can the type of use be determined from a surface survey? With certain limitations, the answer is yes. Residence, tool manufacture, and food collection and processing are reflected in the information gathered in the survey. In addition, human remains were found on 6 sites in the survey. Several trade routes, mentioned earlier, lie within the park, and trade items, though limited in number, have been identified in the survey. The scarcity of trade items, as well as other surface artifacts, may be due to collection of attractive articles by visitors and residents during historic times.

How intensively was the area used? Even given the number of sites included in this survey, intensity of use cannot be determined from a surface survey alone. There are too many unanswered questions. Were the sites used seasonally or permanently? Were they villages or campsites? How long was the period of occupation? Were the sites used contemporaneously?

Radiocarbon dating would provide a time sequence for occupation. Obsidian hydration and sourcing would provide clues both to the time of occupation and to the origin of trade items. Analysis of floral and faunal remains would provide clues to seasonal or permanent occupation. Excavation would provide a temporal sequence and possibly provide clues to the ethnicity of the aboriginal occupants.

In conclusion, a surface survey is only the first of many steps in providing a more complete picture of the earliest residents of the Central Diablo Range. The present survey provides only one certainty: the Central Diablo Range should be the focus of further research. 


\section{WORKS CITED}

Allen, Everett. Interview by author, April 14, 1989, Morgan Hill, California.

Baumhoff, Martin A. "Ecological Determinants of Aboriginal Populations." University of California Publications in American Archaeology and Ethnology 49 (1963): 155-236.

Bean, Lowell John and Harry Lawton. "Some Explanations for the Rise of Cultural Complexity in Native California with Comments on Proto-Agriculture and Agriculture." In Native Californians, a Theoretical Perspective, ed. Lowell J. Bean and Thomas Blackburn. Ramona: Ballena Press, 1974.

Beck, Warren A. and Ynez D. Haase. Historical Atlas of California. Norman: University of Oklahoma Press, 1975.

Bergthold, J.C. "Prehistoric Settlement and Trade Models in the Santa Clara Valley, California." Master's thesis, San Francisco State University, 1982.

Binford, L.R. "Willow Smoke and Dog's Tails: Hunter Gatherer Settlement Patterns and Archaeological Site Formation." American Antiquity 45 (1980): 4-20.

Breckling, Barry. Interview by author, April 14, 1989, Morgan Hill, California.

Breschini, Gary S., Trudy Haversat and Paul Hampson. A Cultural Resources Overview of the Coast and Coast Study Areas. Salinas: Coyote Press, 1983.

Breschini, Gary S. and Trudy Haversat. Archaeological Investigations at CA-FRE-1333, in the White Creek Drainage, Western Fresno County, California. Salinas:

Coyote Press, 1987.

Carlos, Dick. Interview by author, May 30, 1990, Newman, California.

Cook, Sherburne F. "The Conflict Between the California Indian and White Civilization, I: The Indian Versus the Spanish Mission." Ibero Americana 21 (1943).

"The Epidemic of 1830-1833 in California and Oregon." California

Publications in American Archaeology and Ethnology 43 (1955). 
. "The Aboriginal Population of Alameda and Contra Costa Counties,

California." Universtiy of California Anthropological Records 16 (1957): 239-292.

Davenport, Gary. Interview by author, October 15, 1992, Gustine, California.

Elsasser, Albert B. Review of the Prehistory of the Santa Clara Valley Region, California. Salinas: Coyote Press, 1986.

Enos, Peter. Interview by author, January 9, 1993, Morgan Hill, California.

Fredrickson, David. "Early Cultures of the North Coast Ranges." Ph.D. diss., University of California, Davis, 1973.

Hildebrandt, William R. "Prehistoric Hunting Patterns in Central California." Papers on Central California Prehistory 1 (1984).

Hylkema, Mark G. "Some Perspectives on Upland Settlement Patterns of the Central Diablo Range of California." In Proceedings of the 26th Ammal Meeting of the Society for California Archaeology, Pasadena, 1992, 99-119.

King, T.F. Rethinking the Dead at Tiburon. Riverside: Department of Anthropology, University of California, 1971.

Suscol Village (4-Nap-15): An Archaeological Study for Highway

Planning. San Francisco: California Department of Transportation, 1974.

King, T.F. and P.P. Hickman. The Southern Santa Clara Valley: A General Plan for Archaeology. San Felipe Archaeology I. Rohnert Park: Northwest Regional Information Center of the California Archaeological Inventory, 1973.

Kroeber, A.L. Handbook of the Indians of California. Washington D.C.: Bureau of American Ethnology, 1925.

Latta, Frank F. Handbook of the Yokuts Indians. Santa Cruz: Bear State Books, 1977.

Joaquin Murietta and His Wild Horse Gangs. Santa Cruz: Bear State Books, 1980.

Layton, Jim. Interview by author, December 14, 1987, Gilroy, California.

Levy, R. "Costanoan." In Handbook of North American Indians, Vol. 8, California, ed. Robert F. Heizer, 485-495. Washington D.C.: Smithsonian Institution, 1978 
Milliken, Randall. Archaeological Test Excavations at Fourteen Sites Along Highways 101 and 152 Santa Clara and San Benito Counties, California. Vol. 2: History, Ethnohistory, and Historic Archaeology. Davis: Far Western Anthropological Research Group, Inc., 1993.

Moratto, Michael. California Archaeology. Orlando: Academic Press, 1984.

Official Map of the County of Santa Clara, 1866.

Pritchard, William E. Archaeology of the Menjoulet Site, Merced County, California. Sacramento: California Department of Parks and Recreation, 1970.

Stadtler, Phil. Interview by author, November 11, 1991, Hilmar, California.

Stodder, Ann Lucy. Mechanisms and Trends in the Decline of the Costanoan Indian Population of Central California. Salinas: Coyote Press, 1986.

Thomas, George. Interview by author, October 8, 1990, Morgan Hill, California.

Wallace, W.J. "Northern Valley Yokuts." In Handbook of the North American Indians, Vol. 8, California, ed., Robert F. Heizer 462-470. Washington D.C.: Smithsonian Institution, 1978. 
TABLE 1

MILLING STATIONS

\begin{tabular}{|c|c|c|c|}
\hline Site & Location & Mortars & Cupules \\
\hline A-61 & Coyote Creek & 1 & \\
\hline A-87 & Coyote Creek & 1 & \\
\hline A-145 & San Antonio Valley & 5 & \\
\hline A-146 & San Antonio Valley & 5 & \\
\hline A-147 & San Antonio Valley & 1 & 3 possible \\
\hline A-148 & San Antonio Valley & 1 & \\
\hline CA-Sta-207 & Orestimba Creek & 2 & \\
\hline CA-Sta-206 & Orestimba Creek & 6 & \\
\hline CA-Sta-204 & Orestimba Creek & 7 & \\
\hline CA-Sta-233 & Orestimba Creek & 1 & \\
\hline CA-Sta-195 & Orestimba Creek & $8+$ & $4+$ \\
\hline A-115 & Orestimba Creek & 3 & \\
\hline CA-Sta-203 & Orestimba Creek & 21 & \\
\hline A-92 & Orestimba Creek & 4 & \\
\hline CA-Sta-201 & Orestimba Creek & 18 & $3+$ \\
\hline A-131 & Hartman Creek & 4 & \\
\hline CA-Sta-218 & Mustang Flat & $14+$ & $40+$ \\
\hline CA-Sta-231 & Mustang Flat & 2 & \\
\hline A-83 & Red Creek & 5 & 1 \\
\hline A-105 & Red Creek & 2 & \\
\hline$A-36$ & Red Creek & 5 & \\
\hline A-6 & Red Creek & 8 & \\
\hline A-151 & Red Creek & 7 & \\
\hline A- 150 & Red Creek & 1 & \\
\hline A-118 & Red Creek & 4 & \\
\hline A-1 & Robinson Creek & 3 & 3 \\
\hline$A-91$ & Robinson Creek & 7 & \\
\hline A-125 & Pinto Creek & 6 & \\
\hline
\end{tabular}


TABLE 2

\section{SITES IN SURVEY}

\begin{tabular}{|c|c|c|c|c|}
\hline Site & Type & Location & Surveyor & Date \\
\hline A-61 & Milling Station & Coyote Creek & Researcher & 1991 \\
\hline A-15 & Habitation Site & Coyote Creek & Researcher & 1991 \\
\hline A-87 & Milling Station & Coyote Creek & Researcher & 1991 \\
\hline A-135 & Habitation Site & Coyote Creek & Researcher & 1991 \\
\hline A-138 & Habitation Site & Coyote Creek & Researcher & 1991 \\
\hline A-161 & Habitation Site & Coyote Creek & Researcher & 1993 \\
\hline$A-25$ & Habitation Site & Coyote Creek & Researcher & 1991 \\
\hline A-132 & Hahitation Site & Coyote Creek & Researcher & 1991 \\
\hline \multirow[t]{2}{*}{ A-145 } & Habitation Site & & & \\
\hline & and Milling Station & San Antonio Valley & Researcher & 1992 \\
\hline A-146 & Milling Station & San Antonio Valley & Researcher & 1992 \\
\hline A-147 & Milling Station & San Antonio Valley & Researcher & 1992 \\
\hline A-148 & Milling Station & San Antonio Valley & Researcher & 1992 \\
\hline CA-Sta-210 & Bowl mortar & Orestimba Creek & E. Breck Parkman & 1982 \\
\hline \multirow[t]{3}{*}{ CA-Sta-207 } & Habitation Site & & & \\
\hline & and Milling Station & Orestimba Creek & E. Breck Parkman & 1982 \\
\hline & & & Joe D. Hood & 1986 \\
\hline CA-Sta-206 & Milling Station & Orestimba Creek & E. Breck Parkman & 1982 \\
\hline \multirow[t]{2}{*}{ CA-Sta-204 } & Habitation Site & & & \\
\hline & and Milling Station & Orestimba Creek & Joe D. Hood & 1986 \\
\hline A-44 & Habitation Site & Orestimba Creek & Researcher & 1991 \\
\hline$A-45$ & Habitation Site & Orestimba Creek & Researcher & 1991 \\
\hline CA-Sta-238 & Flake Scatter & Orestimba Creek & Joe D. Hood & 1986 \\
\hline A-136 & Habitation Site & Orestimba Creek & Researcher & 1991 \\
\hline CA-Sta-233 & Milling Station & Orestimba Creek & Joe D. Hood & 1986 \\
\hline CA-Sta-195 & Milling Station & Orestimba Creek & E. Breck Parkman & 1982 \\
\hline A-114 & Habitation Site & Orestimba Creek & Researcher & 1990 \\
\hline A-115 & Milling Station & Orestimba Creek & Researcher & 1990 \\
\hline A-155 & Habitation Site & Orestimba Creek & Researcher & 1993 \\
\hline$A-140$ & Habitation Site & Orestimba Creek & Researcher & 1993 \\
\hline CA-Sta-203 & Milling Station & Orestimba Creek & E. Breck Parkman & 1982 \\
\hline A-141 & Habitation Site & Orestimba Creek & Researcher & 1992 \\
\hline A-144 & Habitation Site & Orestimba Creek & Researcher & 1992 \\
\hline A-94 & Habitation Site & Orestimba Creek & Researcher & 1990 \\
\hline
\end{tabular}


TABLE 2 - CONTINUED

\begin{tabular}{|c|c|c|c|c|}
\hline Site & Type & Location & Surveyor & Date \\
\hline A-95 & Habitation Site & Orestimba Creek & Researcher & 1990 \\
\hline A-96 & Habitation Site & Orestimba Creek & Researcher & 1990 \\
\hline A-102 & Hopper Mortar & Orestimba Creek & Researcher & 1990 \\
\hline A-101 & Habitation Site & Orestimba Creek & Researcher & 1990 \\
\hline A-88 & Habitation Site & Orestimba Creek & Researcher & 1990 \\
\hline A-92 & Milling Station & Orestimba Creek & Researcher & 1990 \\
\hline A-93 & Habitation Site & Orestimba Creek & Researcher & 1990 \\
\hline CA-Sta-201 & Milling Station & Orestimba Creek & E. Breck Parkman & 1982 \\
\hline A-99 & Habitation Site & Orestimba Creek & Researcher & 1990 \\
\hline A-128 & Habitation Site & Orestimba Creek & Researcher & 1991 \\
\hline CA-Sta-202 & Milling Station & Orestimba Creek & E. Breck Parkman & 1982 \\
\hline A-35 & Habitation Site & Orestimba Creek & Researcher & 1990 \\
\hline$A-100$ & Habitation Site & Orestimba Creek & Researcher & 1990 \\
\hline$A-37$ & Habitation Site & Orestimba Creek & Researcher & 1990 \\
\hline A-154 & Habitation Site & Hartman Creek & Researcher & 1993 \\
\hline A-129 & Habitation Site & Hartman Creek & Researcher & 1991 \\
\hline$A-130$ & Habitation Site & Hartman Creek & Researcher & 1991 \\
\hline A-131 & Milling Station & Hartman Creek & Researcher & 1991 \\
\hline A-133 & Habitation Site & Hartman Creek & Researcher & 1991 \\
\hline CA-Sta-234 & Habitation Site & Mustang Flat & Joe D. Hood & 1986 \\
\hline CA-Sta-232 & Habitation Site & Mustang Flat & $\begin{array}{l}\text { Joe D. Hood } \\
\text { Researcher }\end{array}$ & $\begin{array}{l}1986 \\
1990\end{array}$ \\
\hline A-113 & Habitation Site & Mustang Flat & Researcher & 1990 \\
\hline CA-Sta-218 & Milling Station & Mustang Flat & Lee Sims, Park Aide & 1984 \\
\hline CA-Sta-231 & Milling Station & Mustang Flat & Joe D. Hood & 1986 \\
\hline CA-Sta-252 & Habitation Site & Red Creek & Researcher & 1988 \\
\hline CA-Sta-253 & Habitation Site & Red Creek & Researcher & 1988 \\
\hline CA-Sta-258 & Flake Scatter & Red Creek & Researcher & 1988 \\
\hline CA-Sta-254 & Habitation Site & Red Creek & Researcher & 1988 \\
\hline$A-75$ & Habitation Site & Red Creek & Researcher & 1988 \\
\hline A-83 & Milling Station & Red Creek & Researcher & 1988 \\
\hline CA-Sta-255 & Habitation Site & Red Creek & Researcher & 1988 \\
\hline A- 105 & Milling Station & Red Creek & Researcher & 1988 \\
\hline CA-Sta-256 & Habitation Site & Red Creek & Researcher & 1988 \\
\hline CA-Sta-257 & Habitation Site & Red Creek & Researcher & 1988 \\
\hline CA-Sta-259 & Habitation Site & Red Creek & Researcher & 1988 \\
\hline
\end{tabular}


TABLE 2 - CONTINUED

$\begin{array}{lllll}\text { Site } & \text { Type } & \text { Location } & \text { Surveyor } & \text { Date } \\ \text { A-7 } & \text { Milling Station } & \text { Red Creek } & \text { Researcher } & 1991 \\ \text { A-36 } & \text { Milling Station } & \text { Red Creek } & \text { Researcher } & 1991 \\ \text { A-152 } & \text { Habitation Site } & \text { Red Creek } & \text { Researcher } & 1992 \\ \text { A-151 } & \text { Milling Station } & \text { Red Creek } & \text { Researcher } & 1992 \\ \text { A-150 } & \text { Milling Station } & \text { Red Creek } & \text { Researcher } & 1992 \\ \text { A-149 } & \text { Habitation Site } & \text { Red Creek } & \text { Researcher } & 1992 \\ \text { A-118 } & \text { Milling Station } & \text { Red Creek } & \text { Researcher } & 1989 \\ \text { A-119 } & \text { Habitation Site } & \text { Paradise Flat } & \text { Researcher } & 1991 \\ \text { CA-Sta-208 } & \text { Hunting Site } & \text { Paradise Flat } & \text { E. Breck Parkman } & 1982 \\ \text { A-120 } & \text { Habitation Site } & \text { Paradise Flat } & \text { Researcher } & 1990 \\ \text { A-139 } & \text { Projectile Point } & \text { Paradise Flat } & \text { Researcher } & 1991 \\ \text { A-103 } & \text { Habitation Site } & \text { Paradise Flat } & \text { Researcher } & 1990 \\ \text { A-104 } & \text { Habitation Site } & \text { Robinson Creek } & \text { Researcher } & 1990 \\ \text { A-1 } & \text { Milling Station } & \text { Robinson Creek } & \text { Researcher } & 1990 \\ \text { A-107 } & \text { Habitation Site } & \text { Robinson Creek } & \text { Researcher } & 1990 \\ \text { A-91 } & \text { Habitation Site/ } & & & \\ & \text { Milling Station } & \text { Robinson Creek } & \text { Researcher } & 1990 \\ \text { A-89 } & \text { Habitation Site } & \text { Robinson Creek } & \text { Researcher } & 1990 \\ \text { A-98 } & \text { Habitation Site } & \text { Robinson Creek } & \text { Researcher } & 1990 \\ \text { A-97 } & \text { Habitation Site } & \text { Robinson Creek } & \text { Researcher } & 1990 \\ \text { A-117 } & \text { Habitation Site } & \text { Pinto Creek } & \text { Researcher } & 1990 \\ \text { A-125 } & \text { Milling Station } & \text { Pinto Creek } & \text { Researcher } & 1991 \\ \text { A-126 } & \text { Habitation Site } & \text { Pinto Creek } & \text { Researcher } & 1991 \\ \text { A-127 } & \text { Habitation Site } & \text { Pinto Creek } & \text { Researcher } & 1991\end{array}$


TABLE 3

\section{VEGETATION, LANDFORM AND ELEVATION}

Site

A-61

A-15

A-87

A-135

A-138

A-161

A-25

A-132

A-145

A-146

A-147

A-148

CA-Sta-210

CA-Sta-207

CA-Sta-206

CA-Sta-204

A-44

A-45

CA-Sta-238

A-136

CA-Sta-233

CA-Sta-195

A-1 14

A-115

A-155

A-140

CA-Sta-203

A-141
Vegetation

oak woodland

oak woodland/grassland

oak woodland

oak woodland

oak woodland

oak woodland

oak woodland

oak woodland

oak woodland/grassland oak woodland/grassland

oak woodland

oak woodland

oak woodland

oak woodland

oak woodland/grassland

oak woodland/riparian

oak woodland

oak woodland

oak woodland

oak woodland

oak woodland

oak woodland/grassland

oak woodland

oak woodland/riparian

oak woodland/chaparral

oak woodland

oak woodland-riparian

oak woodland
Landform

stream-side bench

stream-side bench

stream-side bench

stream-side terrace

stream-side bench

stream-side terrace

stream-side terrace/

confluence

stream-side bench/

confluence

stream-side terrace

stream-side terrace

stream-side/upper canyon

stream-side/upper canyon

canyon bottom

stream-side terrace

valley bottom

canyon bottom/

confluence

stream-side bench

stream-side terrace

stream-side terrace

stream-side terrace/

confluence

canyon

canyon bottom

stream-side bench

streambed

bluff

stream-side terrace

streambed

stream-side terrace
Elevation

$329 \mathrm{~m}$

$329 \mathrm{~m}$

$329 \mathrm{~m}$

$329 \mathrm{~m}$

$305 \mathrm{~m}$

$317-329 m$

$293 m$

$293 \mathrm{~m}$

$658 \mathrm{~m}$

$646 \mathrm{~m}$

$658 \mathrm{~m}$

$658 \mathrm{~m}$

$428 \mathrm{~m}$

$408 \mathrm{~m}$

$418 \mathrm{~m}$

384-402m

$390 \mathrm{~m}$

$378 \mathrm{~m}$

$372 \mathrm{~m}$

$372 \mathrm{~m}$

$366 \mathrm{~m}$

$352 \mathrm{~m}$

$354 \mathrm{~m}$

$341 \mathrm{~m}$

$354 \mathrm{~m}$

$341 \mathrm{~m}$

$329 \mathrm{~m}$

$347 \mathrm{~m}$ 
TABLE 3 - CONTINUED

Site

A-144

A-94

A-95

A-96

A-102

A-101

A- 88

A-92

A-93

CA-Sta-201

A-99

A-128

CA-Sta-202

A-35

A-100

A-37

A-154

A-129

A-130

A-131

A-133

CA-Sta-234

CA-Sta-234

A-113

CA-Sta-218

CA-Sta-231

CA-Sta-252

CA-Sta-253
Vegetation

oak woodland

oak woodland

oak woodland

oak woodland/chaparral

oak woodland

oak woodland/chaparral

oak woodland

oak woodland

oak woodland

riparian

oak woodland

oak woodland

oak woodland

oak woodland

oak woodland

oak woodland/chaparral

oak woodland

oak woodland

oak woodland

oak woodland

oak woodland

oak woodland

oak woodland

oak woodland

oak woodland

oak woodland

oak woodland

oak woodland
Location

Elevation

stream-side bench/

confluence

$329 \mathrm{~m}$

stream-side terrace

stream-side terrace/

confluence

$305 \mathrm{~m}$

bluff

$305 \mathrm{~m}$

hillside/upper canyon

stream-side terrace/

upper canyon

stream-side terrace/

confluence

stream-side bench/

upper canyon

stream-side bench/

upper canyon

streambed

stream-side bench

stream-side bench/

confluence

canyon bottom

stream-side bench/

confluence

stream-side bench

hillside bench

stream-side terrace

stream-side bench

stream-side bench

hillside

hilltop

knoll

stream-side terrace

stream-side bench

canyon

canyon

stream-side bench

stream-side bench

60
$329 \mathrm{~m}$

$378 \mathrm{~m}$

$354 \mathrm{~m}$

$305 \mathrm{~m}$

$341 \mathrm{~m}$

$366 \mathrm{~m}$

$293 \mathrm{~m}$

$293 \mathrm{~m}$

$305 \mathrm{~m}$

$280 \mathrm{~m}$

$280 \mathrm{~m}$

$280 \mathrm{~m}$

$317 \mathrm{~m}$

$366 \mathrm{~m}$

$415 \mathrm{~m}$

$415 \mathrm{~m}$

$428 \mathrm{~m}$

$402 \mathrm{~m}$

$381 \mathrm{~m}$

$390 \mathrm{~m}$

$354 \mathrm{~m}$

$366 \mathrm{~m}$

$366 \mathrm{~m}$

$366 \mathrm{~m}$

$354 \mathrm{~m}$ 
TABLE 3 - CONTINUED

Site

CA-Sta-258

CA-Sta-254

A-75

A-83

CA-Sta-255

A-105

CA-Sta-256

CA-Sta-257

CA-Sta-259

A-7

A-36

A- 152

A-151

A-150

A-149

A-118

A-119

CA-Sta-208

A- 120

A-139

A-103

A-104

A-1

A-107

A-91

A-89

A-98

A-97

A-117

A-125

A-126

A- 127
Vegetation

oak woodland

oak woodland

oak woodland

oak woodland

oak woodland

oak woodland

oak woodland

oak woodland

oak woodland

oak woodland

oak woodland

oak woodland

oak woodland

oak woodland

oak woodland/riparian

oak woodland/riparian

oak woodland/grassland

grassland

oak woodland/grassland

chaparral

oak woodland

oak woodland

oak woodland

oak woodland

oak woodland

oak woodland

oak woodland

oak woodland

oak woodland

oak woodland

oak woodland

oak woodland
Location

Elevation

stream-side bench

$378 \mathrm{~m}$

stream-side bench

stream-side bench

stream-side terrace

stream-side bench

stream-side bench

stream-side bench

stream-side bench

stream-side bench

canyon bank

canyon bank

stream-side bench

stream-side bench

streamside

stream-side bench

stream-side bench

flat

knolitop

flat

flat

bluff

stream-side bench

stream-side bench

stream-side bench

stream-side bench

stream-side bench

stream-side bench

stream-side bench

stream-side bench

ridge

hillside bench

stream-side bench
$378 \mathrm{~m}$

$366 \mathrm{~m}$

$366 \mathrm{~m}$

$402 \mathrm{~m}$

$402 \mathrm{~m}$

$415 \mathrm{~m}$

$415 \mathrm{~m}$

$402 \mathrm{~m}$

$463 \mathrm{~m}$

$451 \mathrm{~m}$

$512 \mathrm{~m}$

$536 \mathrm{~m}$

$530 \mathrm{~m}$

$524 \mathrm{~m}$

$561 \mathrm{~m}$

$354 \mathrm{~m}$

$367 \mathrm{~m}$

$354 \mathrm{~m}$

$366 \mathrm{~m}$

$390 \mathrm{~m}$

$390 \mathrm{~m}$

$341 \mathrm{~m}$

$341 \mathrm{~m}$

$305 \mathrm{~m}$

$293 \mathrm{~m}$

$293 \mathrm{~m}$

$293 \mathrm{~m}$

$366 \mathrm{~m}$

$378 \mathrm{~m}$

$390 \mathrm{~m}$

$390 \mathrm{~m}$ 


\section{TABLE 4}

\section{HOUSEPITS}

$\begin{array}{lll}\text { Site } & \text { Location } & \text { Number } \\ \text { A-161 } & \begin{array}{l}\text { Coyote Creek } \\ \text { San Antonio }\end{array} & 1-2 \text { more possible } \\ \text { A-145 } & \begin{array}{l}\text { Valley } \\ \end{array} & 6 \\ \text { CA-Sta-204 } & \text { Orestimba Creek } & 1 \\ \text { A-136 } & \text { Orestimba Creek } & 2 \text { possible } \\ \text { A-144 } & \text { Orestimba Creek } & 1 \text { possible } \\ \text { A-96 } & \text { Orestimba Creek } & 16 \\ \text { A-88 } & \text { Orestimba Creek } & 17 \\ \text { A-128 } & \text { Orestimba Creek } & 2-3 \text { more possible } \\ \text { A-35 } & \text { Orestimba Creek } & 22 \\ \text { A-133 } & \text { Hartman Creek } & 1 \\ \text { CA-Sta-232 } & \text { Mustang Flat } & 6-5 \text { more possible } \\ \text { A-75 } & \text { Red Creek } & 4 \text { possible } \\ \text { CA-Sta-255 } & \text { Red Creek } & 12 \\ \text { CA-Sta-256 } & \text { Red Creek } & 8 \\ \text { CA-Sta-257 } & \text { Red Creek } & 6 \\ \text { A-104 } & \text { Robinson Creek } & 4-2 \text { more possible } \\ \text { A-107 } & \text { Robinson Creek } & 2 \\ \text { A-89 } & \text { Robinson Creek } & 9 \\ \text { A-98 } & \text { Robinson Creek } & 1 \\ \text { A-117 } & \text { Pinto Creek } & 8-1 \text { more possible }\end{array}$


TABLE 5

\section{MIDDEN SIZE OF HABITATION SITES}

Site

A-15

A-135

A-138

A-161

A-25

A-132

A-145

CA-Sta-207

CA-Sta-204

A-44

A-45

A-136

A-1 14

A-155

A-140

A-141

A-144

A-94

A-95

A-96

A-101

A- 88

A-93

A-99

A-128

A-35
Location

Coyote Creek

Coyote Creek

Coyote Creek

Coyote Creek

Coyote Creek

Coyote Creek

San Antonio Valley

Orestimba Creek

Orestimba Creek

Orestimba Creek

Orestimba Creek

Orestimba Creek

Orestimba Creek

Orestimba Creek

Orestimba Creek

Orestimba Creek

Orestimba Creek

Orestimba Creek

Orestimba Creek

Orestimba Creek

Orestimba Creek

Orestimba Creek

Orestimba Creek

Orestimba Creek

Orestimba Creek

Orestimba Creek
Midden area

$1696 \mathrm{~m}^{2}$

$2153 \mathrm{~m}^{2}$

$1059 \mathrm{~m}^{2}$

$1644 \mathrm{~m}^{2}$

$5781 \mathrm{~m}^{2}$

$872 \mathrm{~m}^{2}$

$1833 \mathrm{~m}^{2}$

$9058 \mathrm{~m}^{2}$

$1200 \mathrm{~m}^{2}$

$443 \mathrm{~m}^{2}$

$71 \mathrm{~m}^{2}$

$455 \mathrm{~m}^{2}$

$901 \mathrm{~m}^{2}$

$286 \mathrm{~m}^{2}$

N/A

$260 \mathrm{~m}^{2}$

$611 \mathrm{~m}^{2}$

$1462 \mathrm{~m}^{2}$

$2312 \mathrm{~m}^{2}$

$1948 \mathrm{~m}^{2}$

$465 \mathrm{~m}^{2}$

$660 \mathrm{~m}^{2}$

$55 \mathrm{~m}^{2}$

$325 \mathrm{~m}^{2}$

$616 \mathrm{~m}^{2}$

$4147 \mathrm{~m}^{2}$ 
TABLE 5 - CONTINUED

Site

A-100

A-37

A-154

A-129

A-130

A-133

CA-Sta-234

CA-Sta-232

A-113

CA-Sta-252

CA-Sta-253

CA-Sta-254

A-75

CA-Sta-255

CA-Sta-256

CA-Sta-257

CA-Sta-259

A-152

A-149

A-119

A-120

A-103

A-104

A-107

A-91

A-89
Location

Orestimba Creek

Orestimba Creek

Hartman Creek

Hartman Creek

Hartman Creek

Hartman Creek

Mustang Flat

Mustang Flat

Mustang Flat

Red Creek

Red Creek

Red Creek

Red Creek

Red Creek

Red Creek

Red Creek

Red Creek

Red Creek

Red Creek

Paradise Flat

Paradise Flat

Paradise Flat

Robinson Creek

Robinson Creek

Robinson Creek

Robinson Creek
Midden area

$363 \mathrm{~m}^{2}$

$207 \mathrm{~m}^{2}$

$147 \mathrm{~m}^{2}$

$488 \mathrm{~m}^{2}$

$267 \mathrm{~m}^{2}$

$1120 \mathrm{~m}^{2}$

$153 \mathrm{~m}^{2}$

$6861 \mathrm{~m}^{2}$

$792 \mathrm{~m}^{2}$

$1112 \mathrm{~m}^{2}$

$680 \mathrm{~m}^{2}$

$471 \mathrm{~m}^{2}$

$247 \mathrm{~m}^{2}$

$1499 \mathrm{~m}^{2}$

$855 \mathrm{~m}^{2}$

$462 \mathrm{~m}^{2}$

$549 \mathrm{~m}^{2}$

$16 \mathrm{~m}^{2}$

$121 \mathrm{~m}^{2}$

$1194 \mathrm{~m}^{2}$

$1665 \mathrm{~m}^{2}$

$1257 \mathrm{~m}^{2}$

$632 \mathrm{~m}^{2}$

$792 \mathrm{~m}^{2}$

$2356 \mathrm{~m}^{2}$

$840 \mathrm{~m}^{2}$ 


\section{TABLE 5 - CONTINUED}

Site

A-98

A-97

A-117

A-126

A-127
Location

Robinson Creek

Robinson Creek

Pinto Creek

Pinto Creek

Pinto Creek
Midden area

$1777 \mathrm{~m}^{2}$

$1414 \mathrm{~m}^{2}$

$679 \mathrm{~m}^{2}$

$328 \mathrm{~m}^{2}$

$63 \mathrm{~m}^{2}$ 


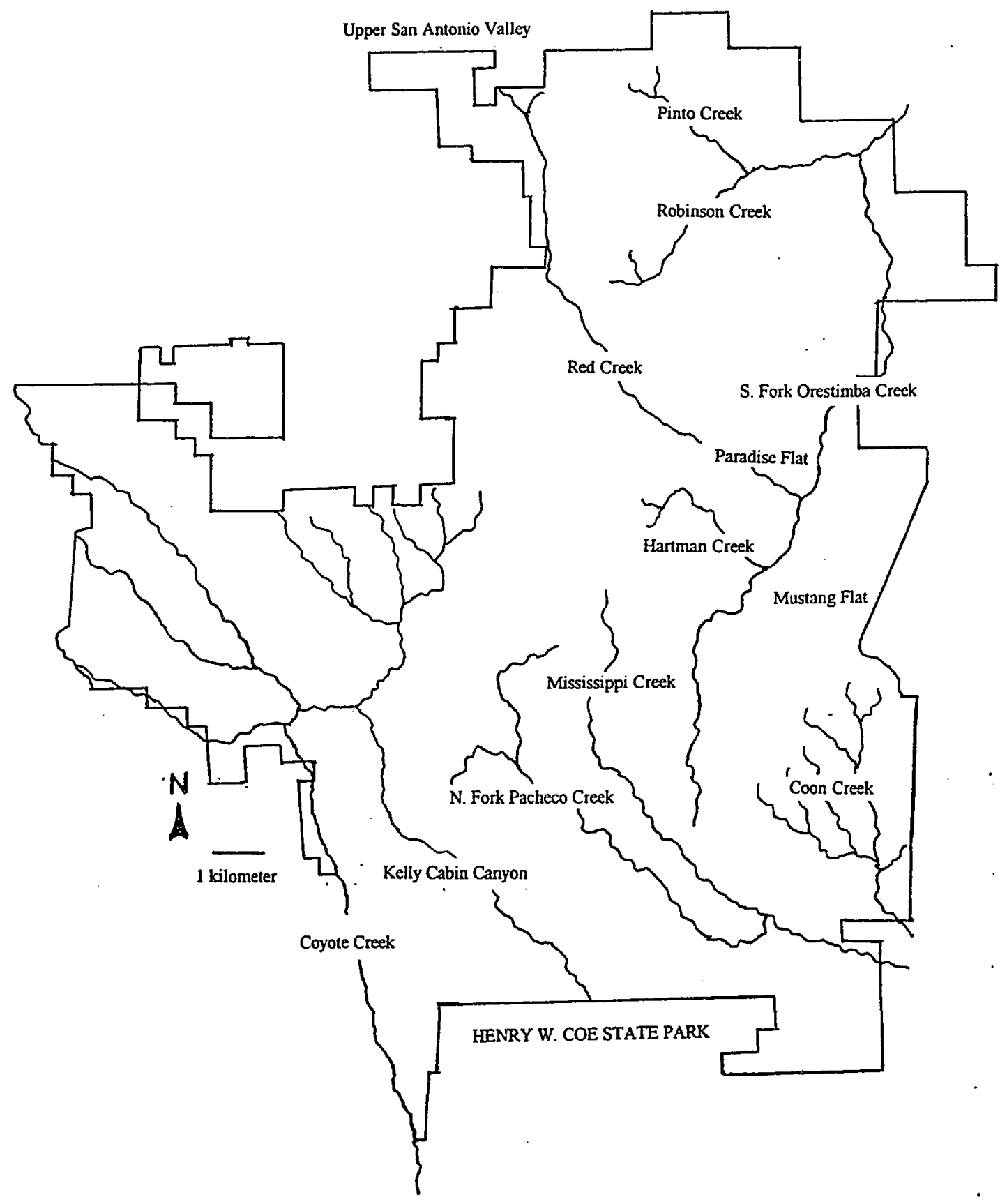

MAP 1. HENRY W. COE STATE PARK 


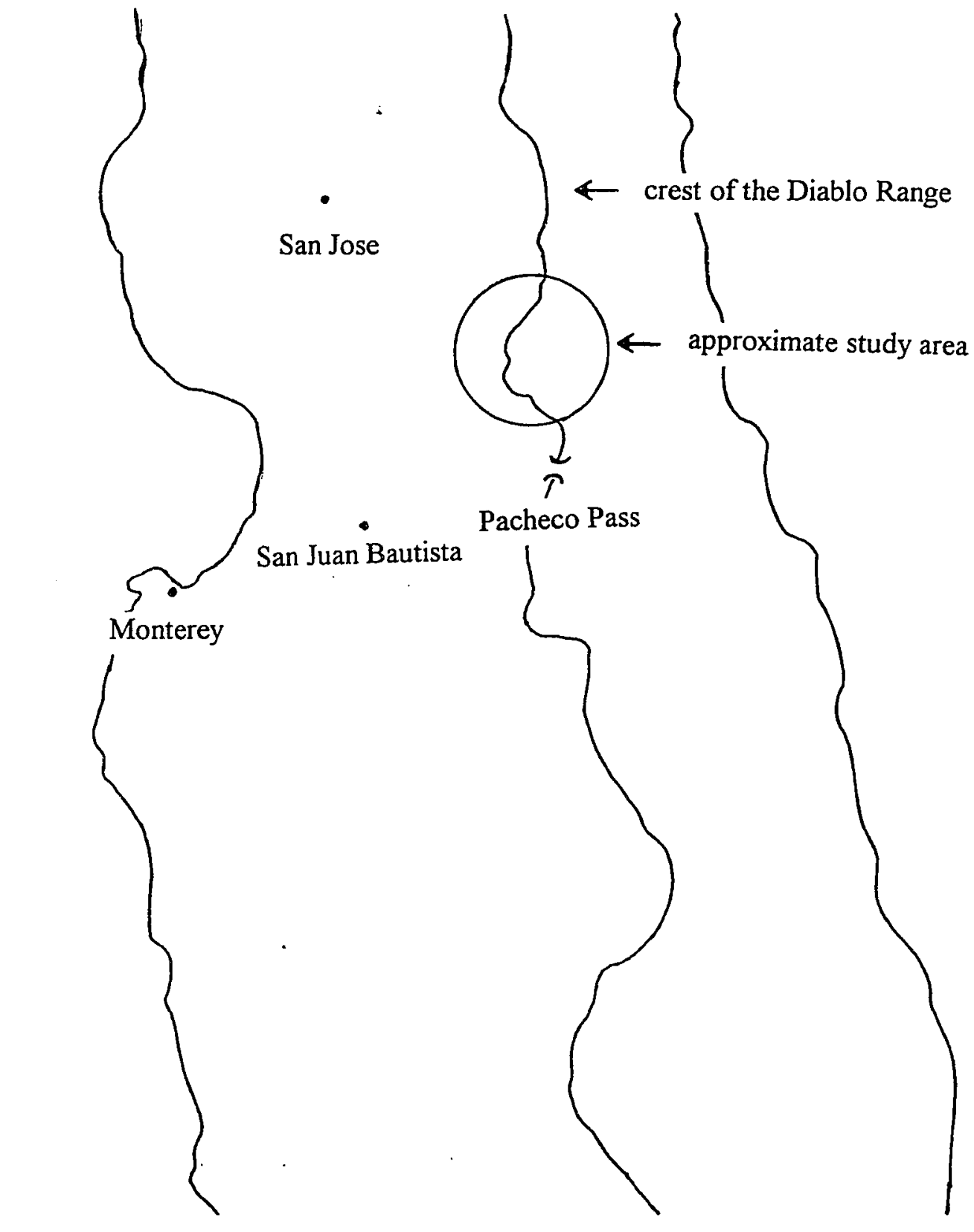

MAP 2. LOCATION OF THE STUDY AREA 


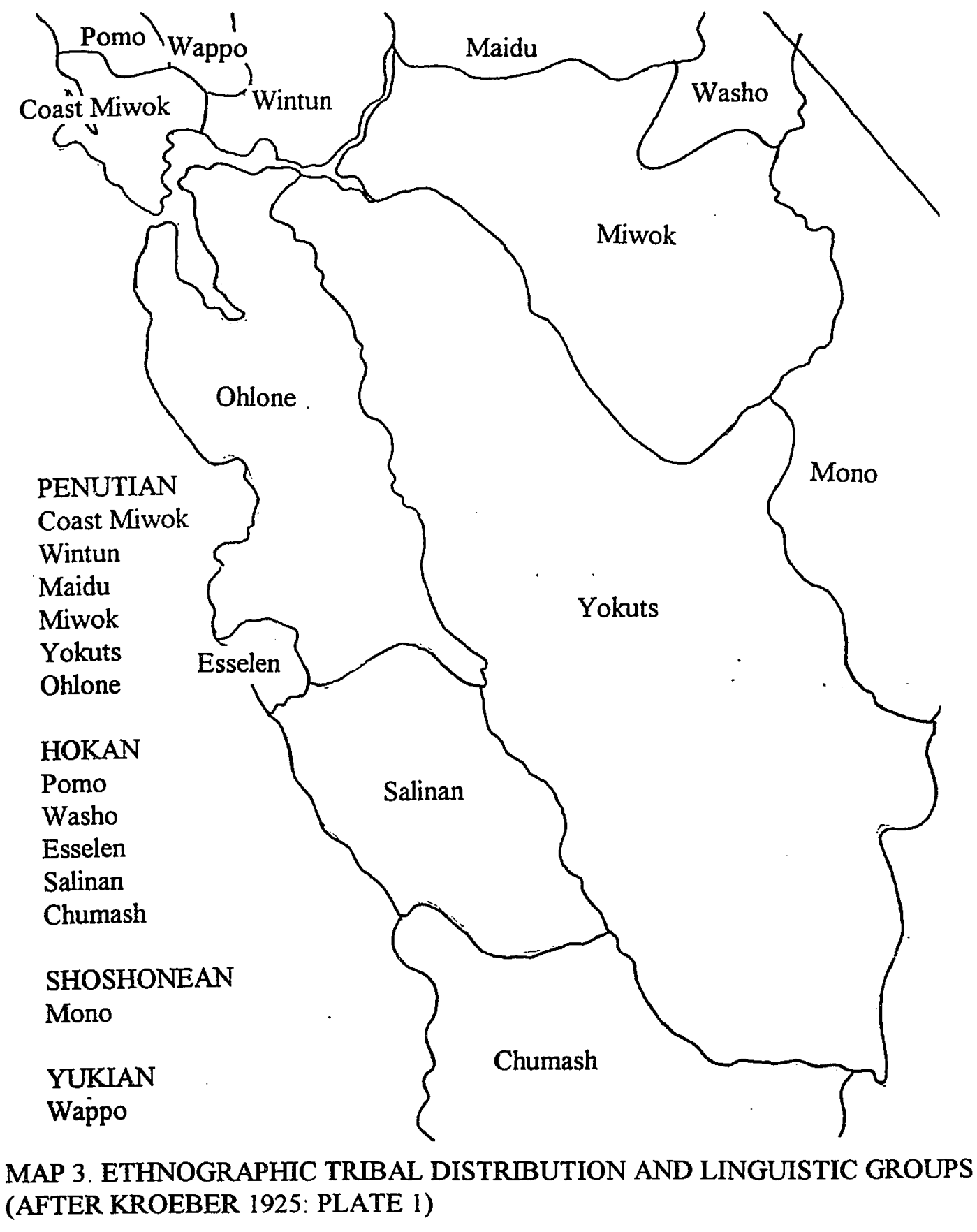




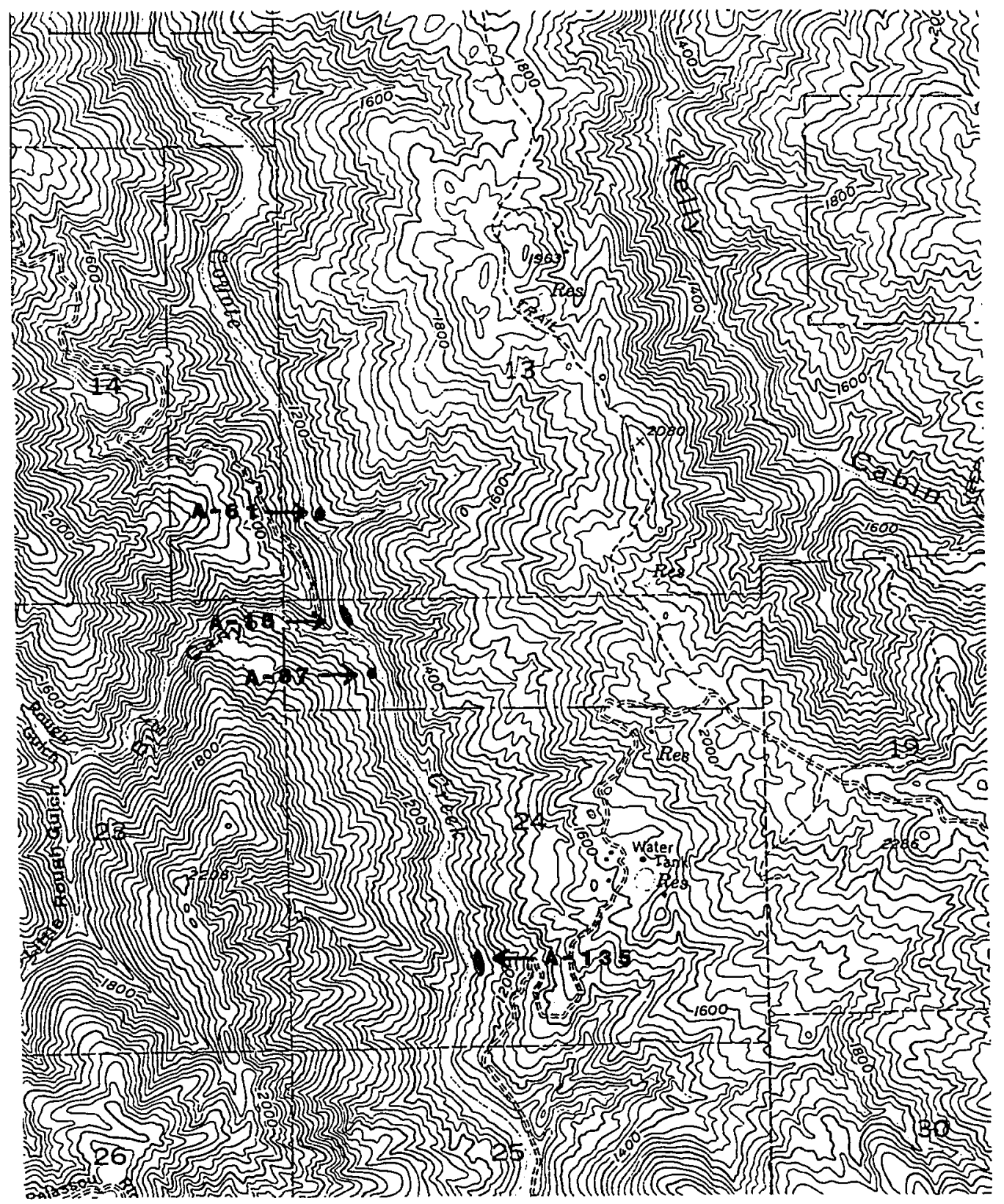

A PORTION OF THE MISSISSIPPI CREEK QUADRANGLE

7.5 MINUTE

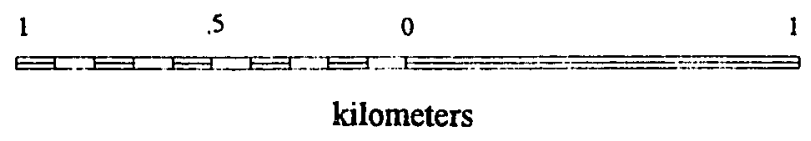

MAP 4. SITES ALONG COYOTE CREEK 


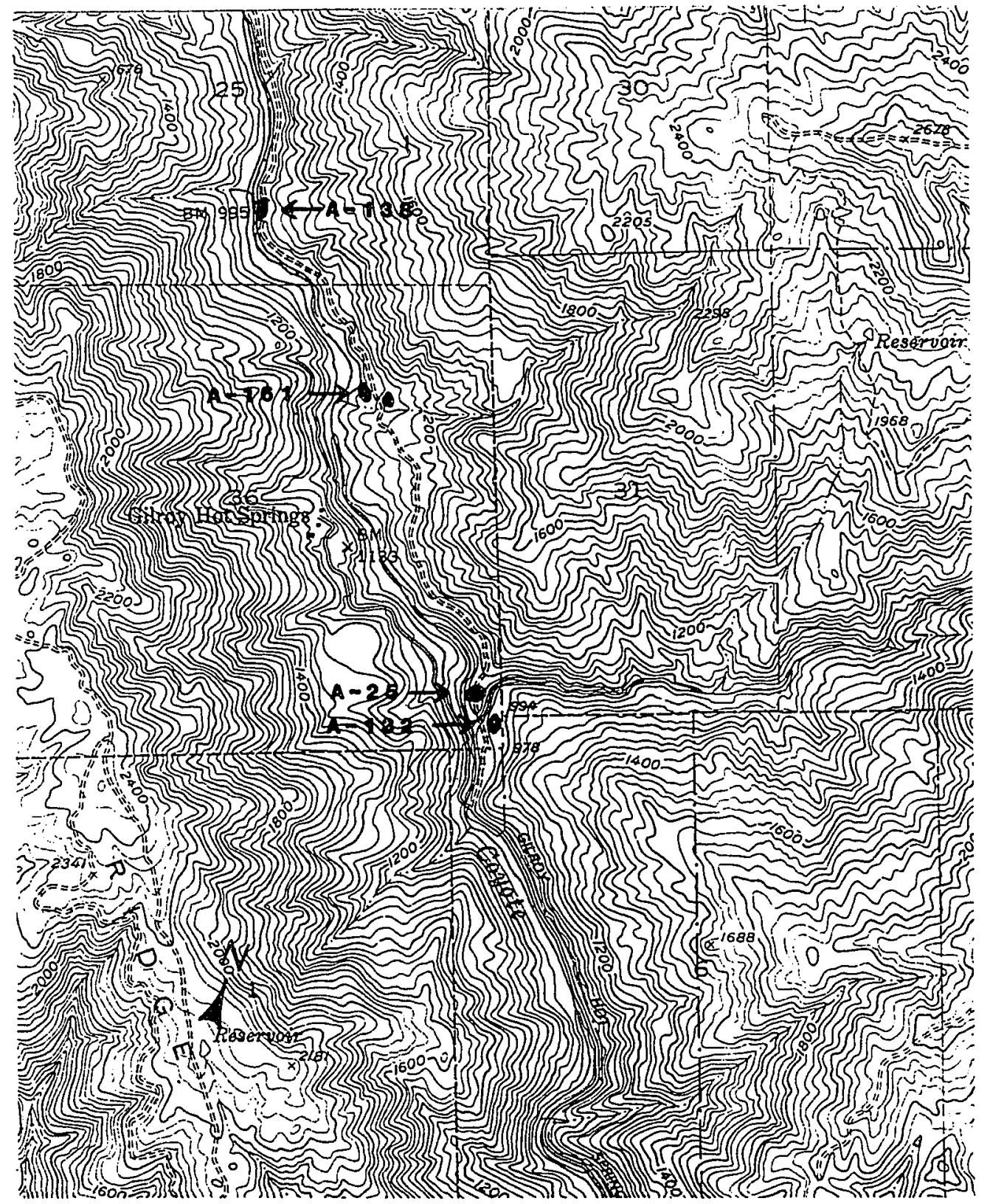

A PORTION OF THE GILROY HOT SPRINGS QUADRANGLE

7.5 MINUTE

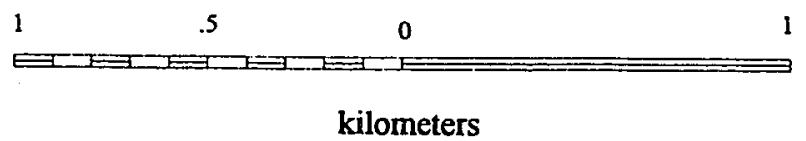

MAP 5. SITES ALONG COYOTE CREEK 


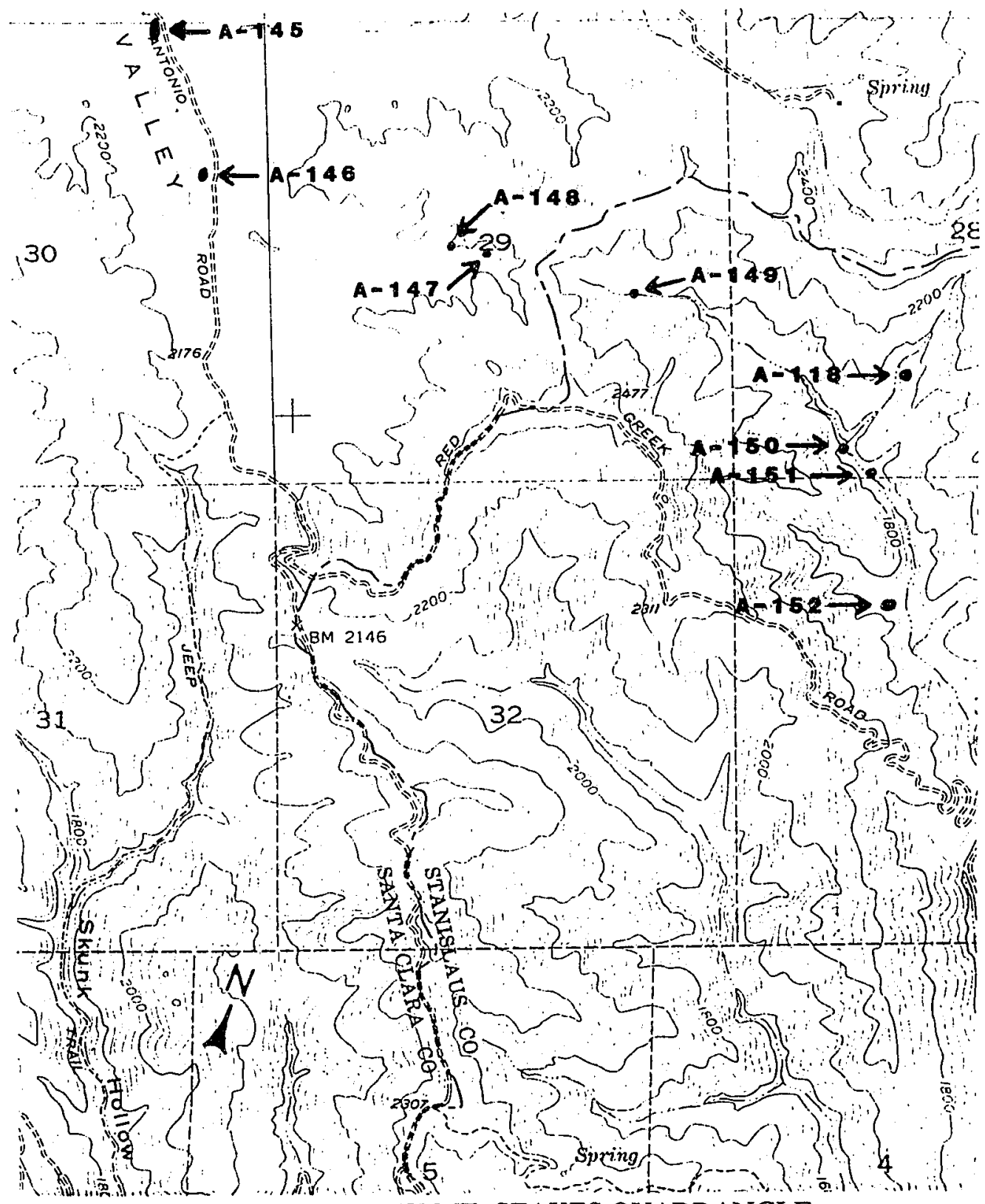

A PORTION OF THE MT. STAKES QUADRANGLE 7.5 MINUTE

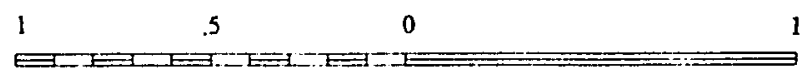

kilometers

MAP 6. SITES IN THE UPPER SAN ANTONIO VALLEY AND ALONG RED CREEK 


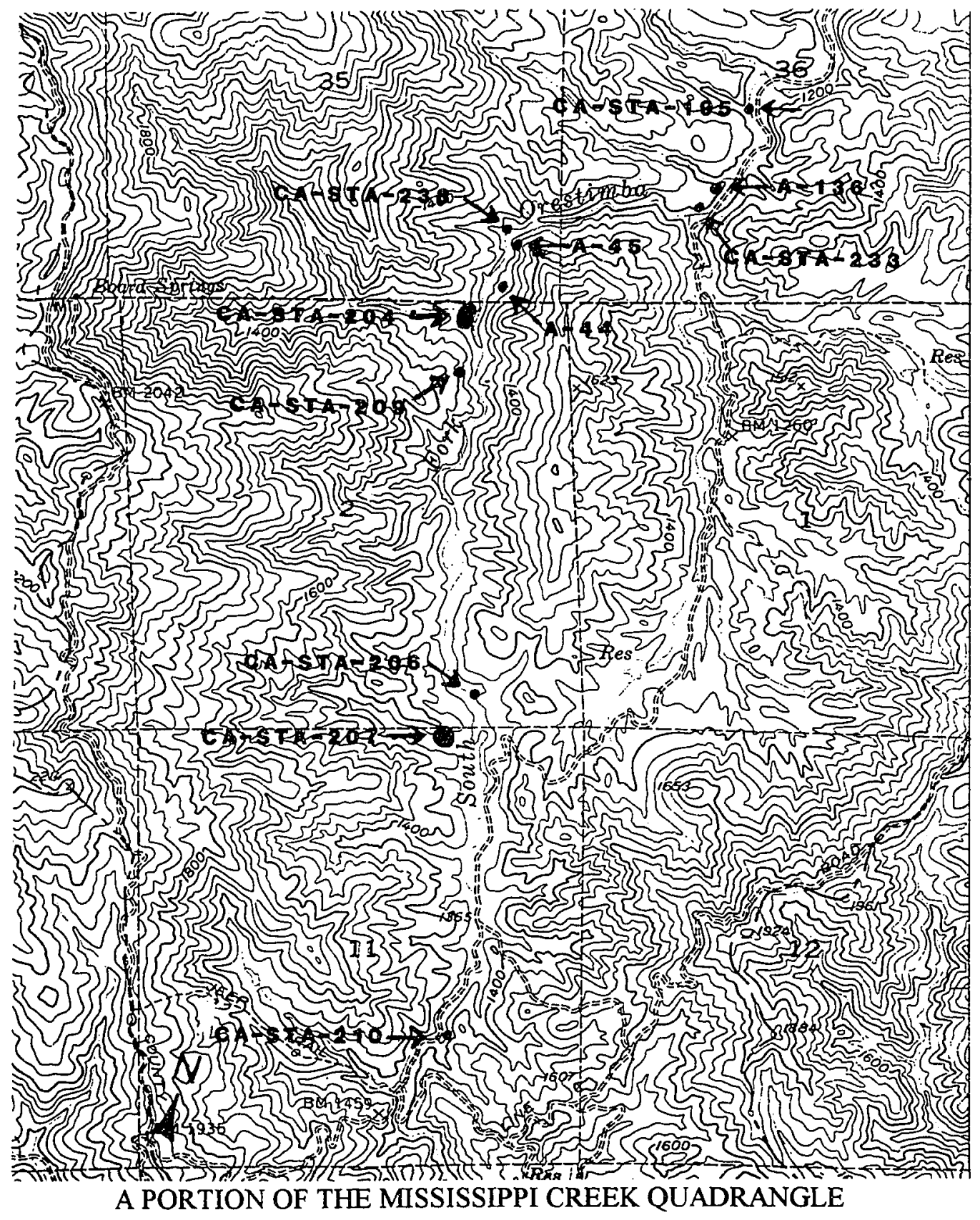

7.5 MINUTE

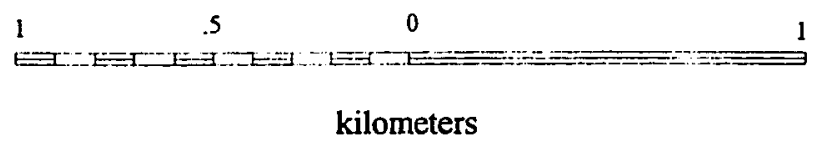

MAP 7. SITES ALONG THE SOUTH FORK OF ORESTIMBA CREEK 


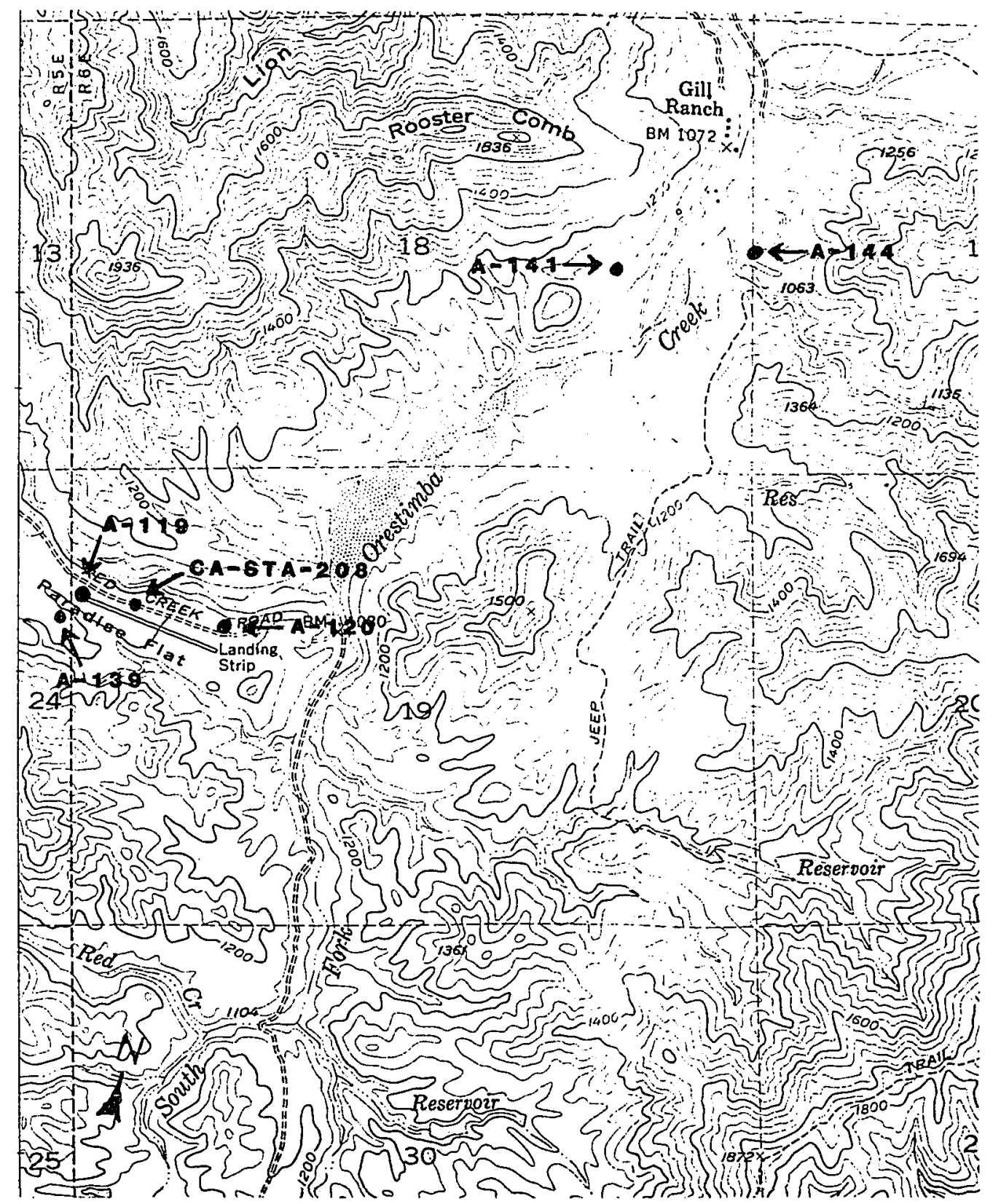

A PORTION OF THE MUSTANG PEAK QUADRANGLE 7.5 MINUTE

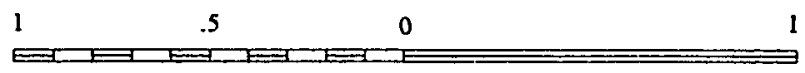

kilometers

MAP 8. SITES ALONG THE SOUTH FORK OF ORESTIMBA CREEK AND PARADISE FLAT 


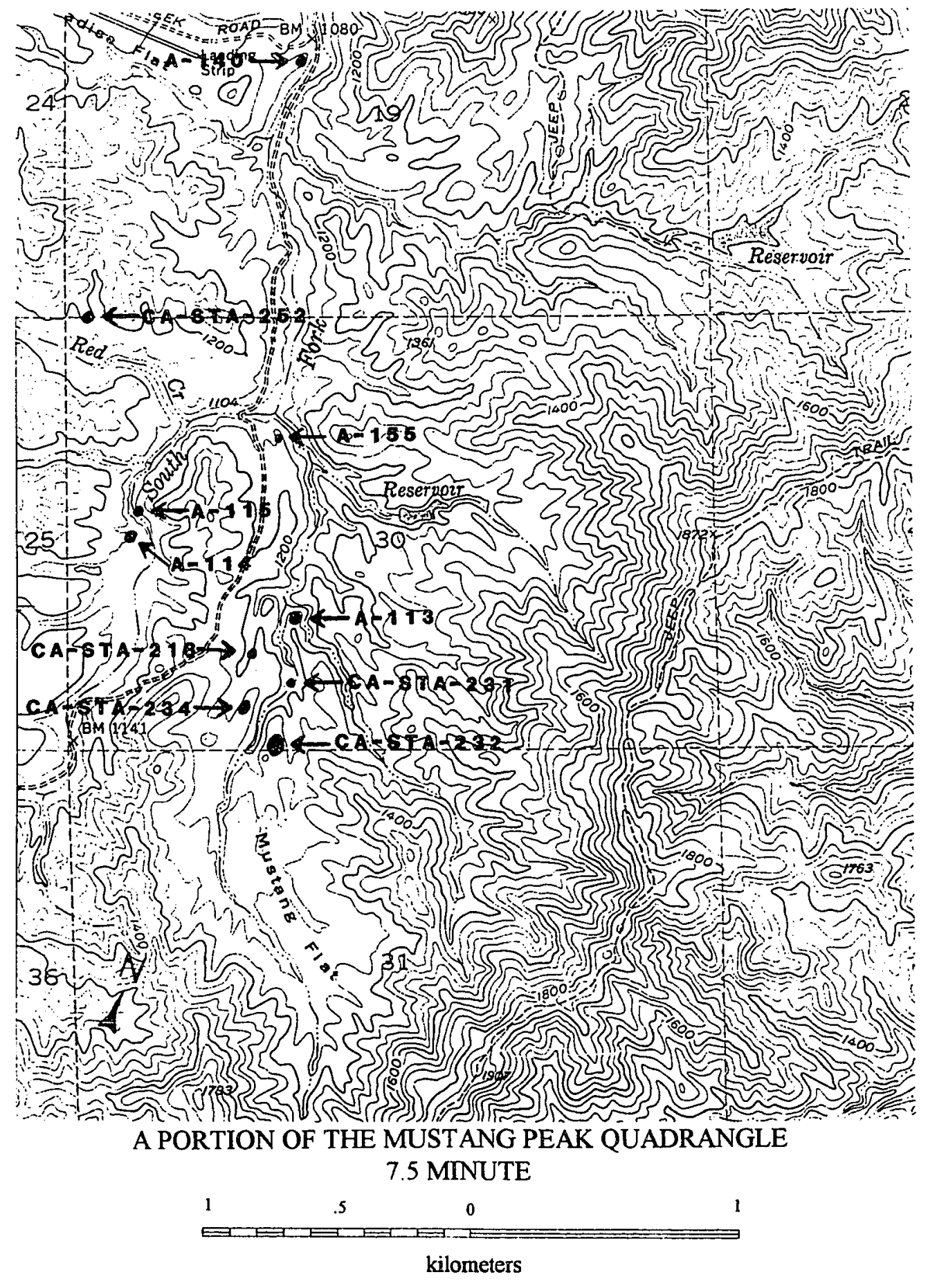

MAP 9. SITES ALONG THE SOUTH FORK OF ORESTIMBA CREEK, PARADISE FLAT, RED CREEK, AND MUSTANG FLAT 

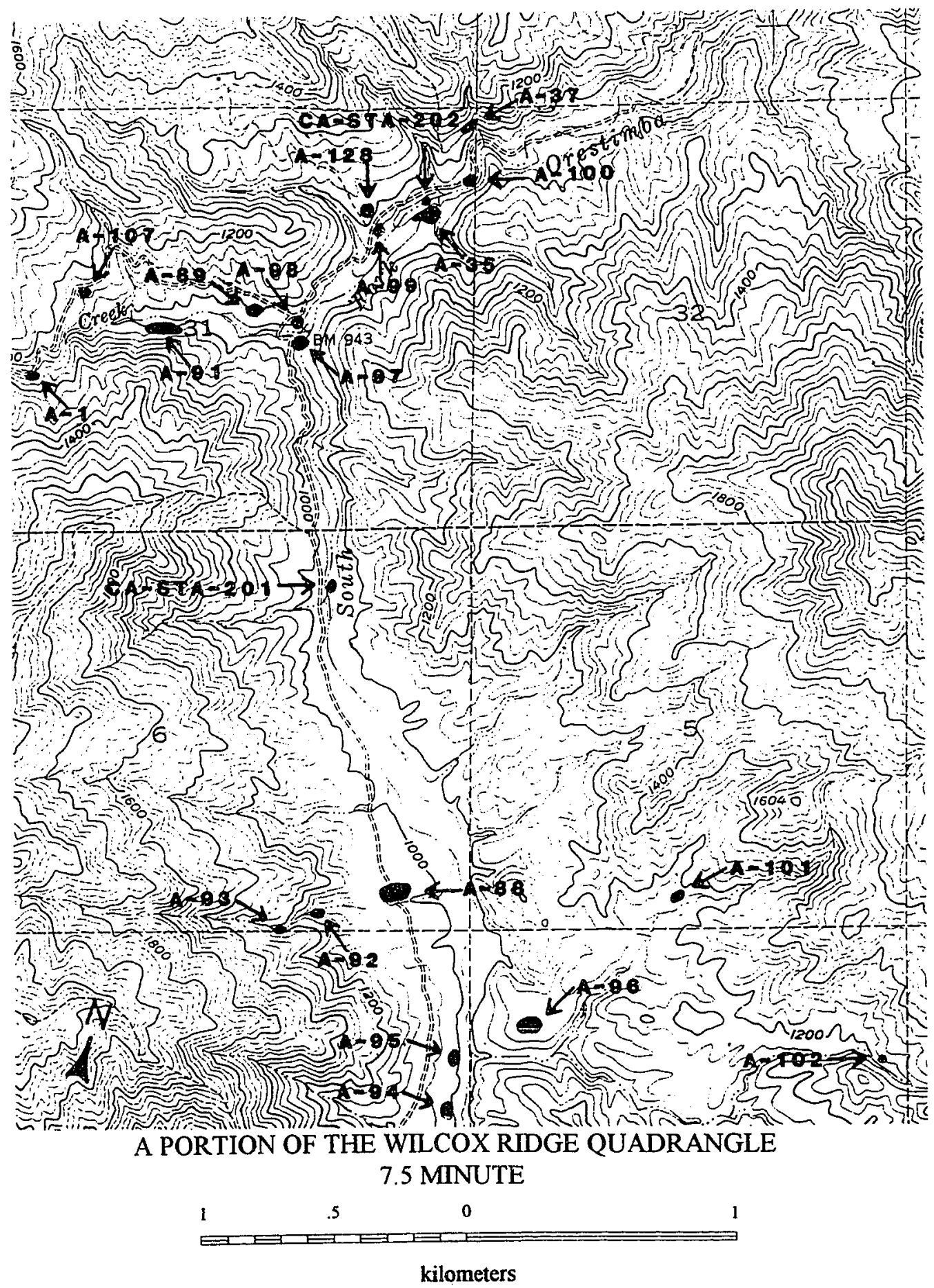

MAP 10. SITES ALONG THE SOUTH FORK OF ORESTIMBA CREEK AND ROBINSON CREEK 


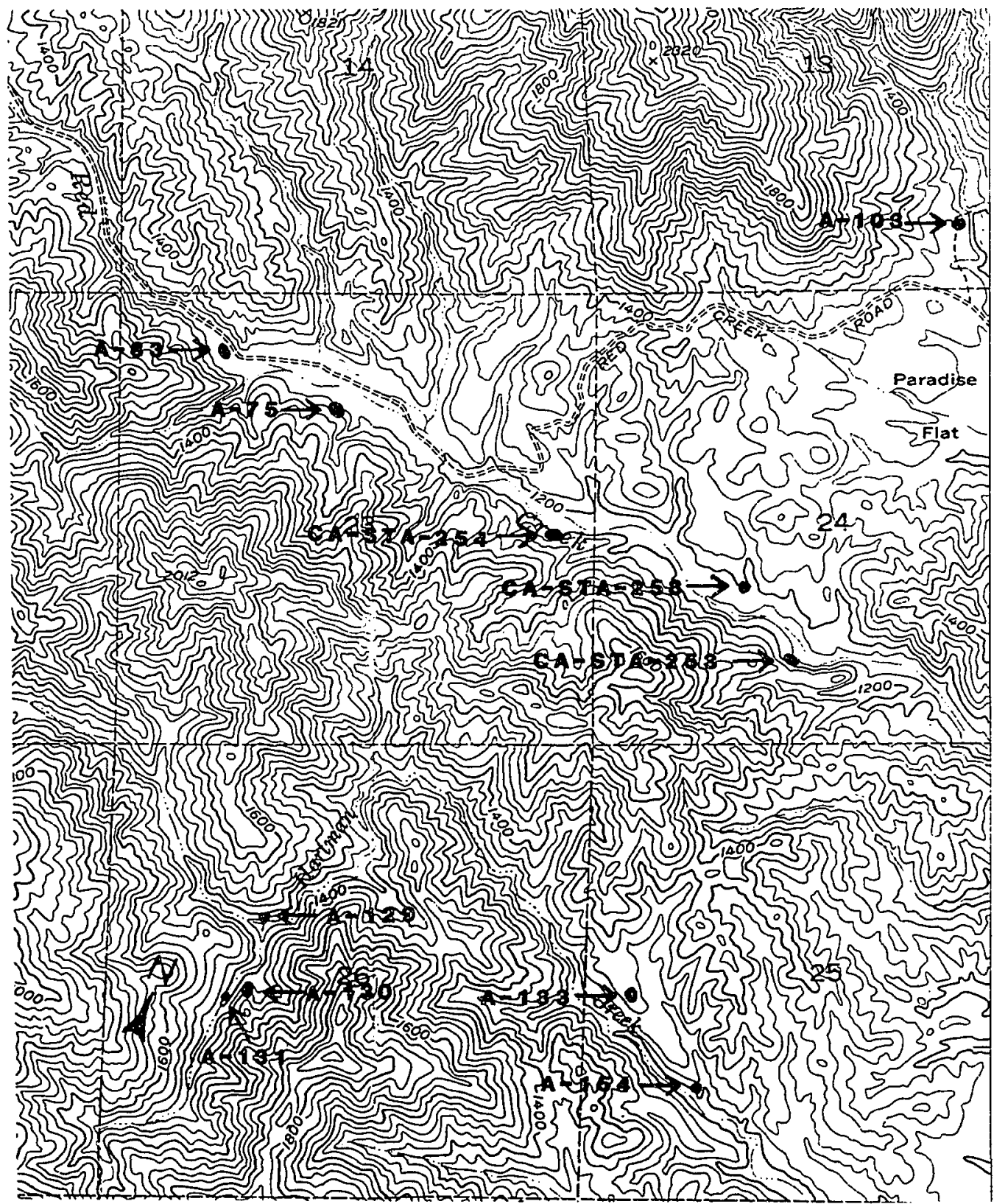

A PORTION OF THE MISSISSIPPI CREEK QUADRANGLE

7.5 MINUTE

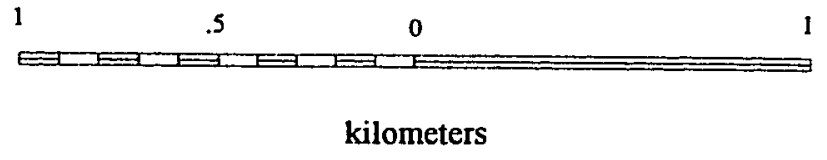

MAP 11. SITES ALONG RED CREEK AND HARTMAN CREEK 


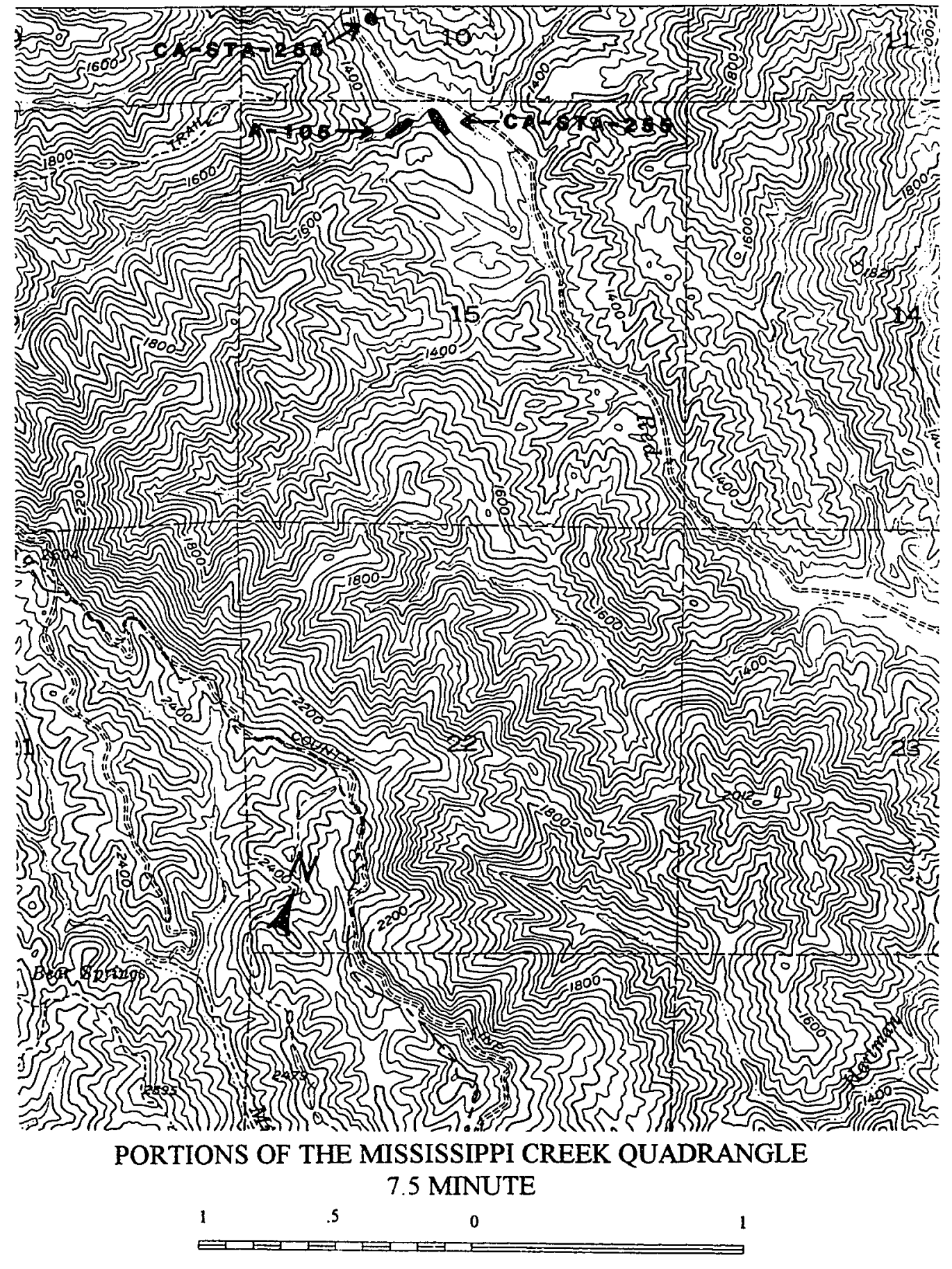

kilometers

MAP 12. SITES ALONG RED CREEK 


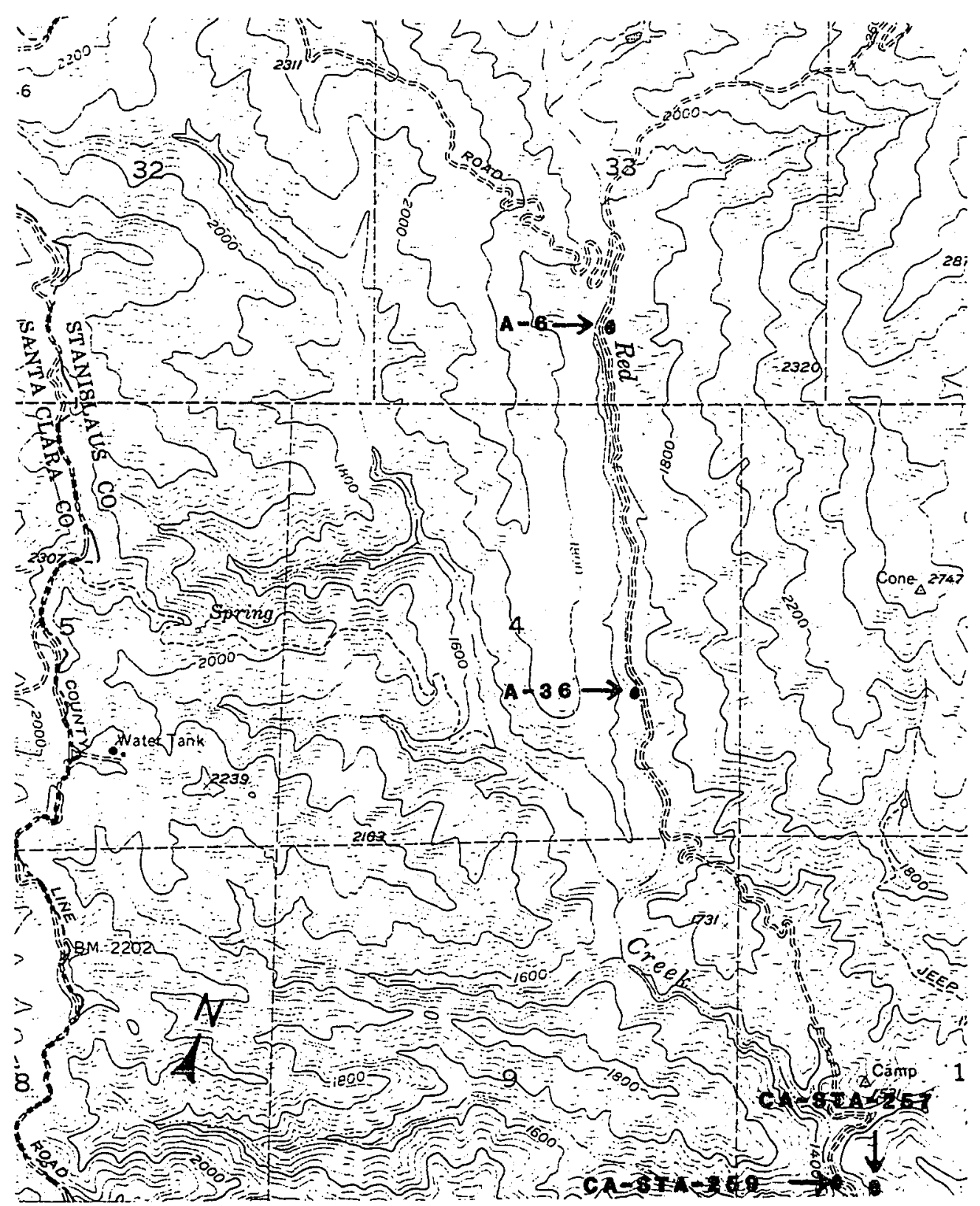

\section{A PORTION OF THE MT. STAKES QUADRANGLE}

7.5 MINUTE

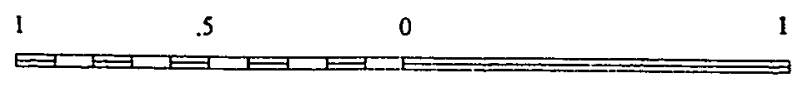

kilometers

MAP 13. SITES ALONG RED CREEK 


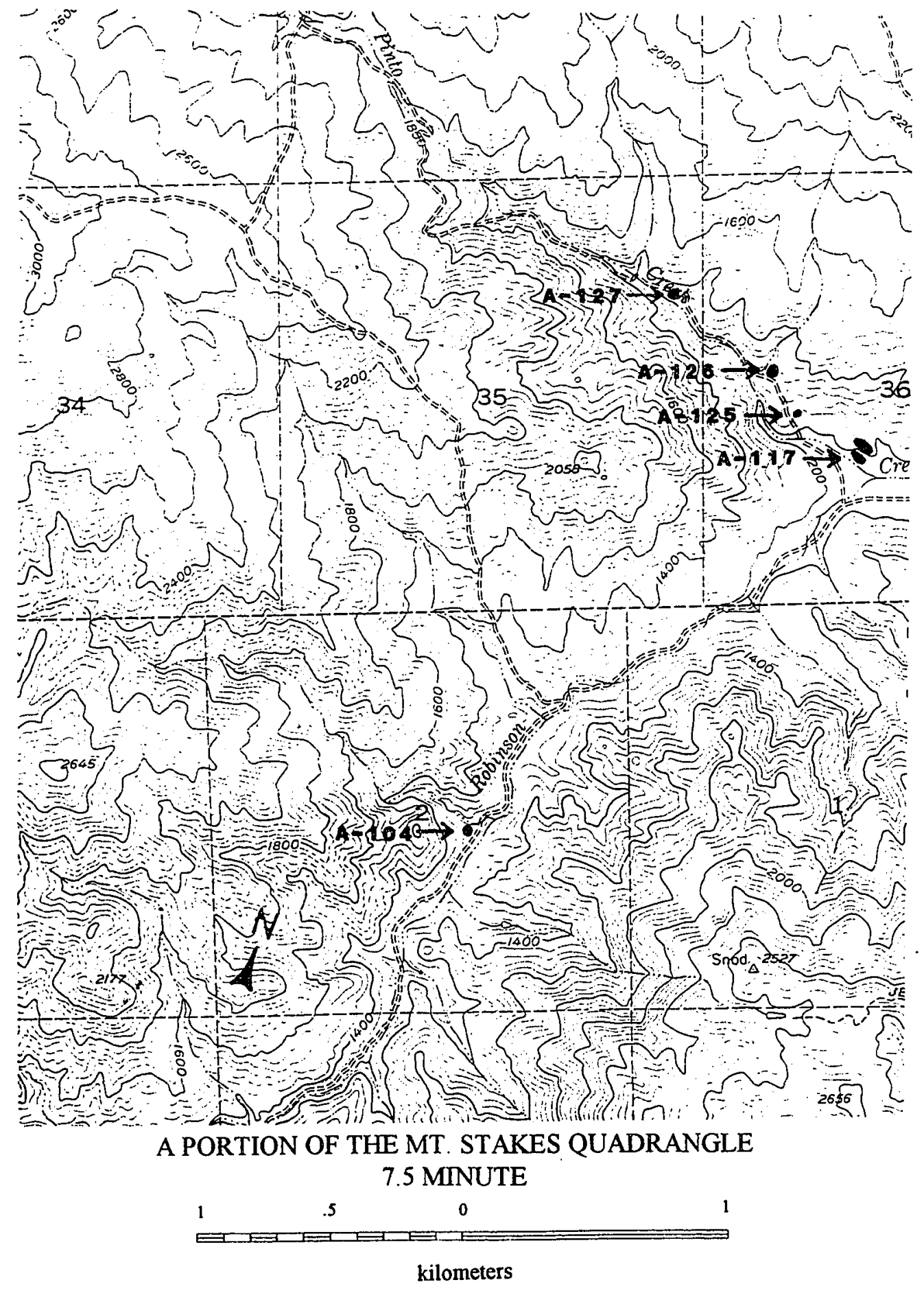

MAP 14. SITES ALONG ROBINSON AND PINTO CREEKS 